\title{
Chemokine receptor-specific antibodies in cancer immunotherapy: achievements and challenges
}

\author{
Maria Vela ${ }^{1}$, Mariana Aris ${ }^{2}$, Mercedes Llorente ${ }^{3}$, Jose A. Garcia-Sanz ${ }^{4}$ and Leonor Kremer ${ }^{1,3}$ * \\ 1 Department of Immunology and Oncology, Centro Nacional de Biotecnología, Consejo Superior de Investigaciones Científicas (CNB/CSIC), Madrid, Spain \\ ${ }^{2}$ Centro de Investigaciones Oncológicas, Fundación Cáncer, Buenos Aires, Argentina \\ ${ }^{3}$ Protein Tools Unit, Centro Nacional de Biotecnología, Consejo Superior de Investigaciones Científicas (CNB/CSIC), Madrid, Spain \\ ${ }^{4}$ Department of Cellular and Molecular Medicine, Centro de Investigaciones Biológicas, Consejo Superior de Investigaciones Científicas (CIB/CSIC), Madrid, Spain
}

\section{Edited by:}

Lee Mark Wetzler, Boston University School of Medicine, USA

\section{Reviewed by:}

Nejat K. Egilmez, University of Louisville, USA

Daniel Olive, Institut Paoli-Calmettes, France

*Correspondence:

Leonor Kremer, Department of Immunology and Oncology, Centro Nacional de Biotecnología (CNB/CSIC), Darwin 3, Cantoblanco, Madrid 28049, Spain

e-mail:Ikremer@cnb.csic.es
The 1990s brought a burst of information regarding the structure, expression pattern, and role in leukocyte migration and adhesion of chemokines and their receptors. At that time, the FDA approved the first therapeutic antibodies for cancer treatment. A few years later, it was reported that the chemokine receptors CXCR4 and CCR7 were involved on directing metastases to liver, lung, bone marrow, or lymph nodes, and the over-expression of CCR4, CCR6, and CCR9 by certain tumors. The possibility of inhibiting the interaction of chemokine receptors present on the surface of tumor cells with their ligands emerged as a new therapeutic approach. Therefore, many research groups and companies began to develop small molecule antagonists and specific antibodies, aiming to neutralize signaling from these receptors. Despite great expectations, so far, only one anti-chemokine receptor antibody has been approved for its clinical use, mogamulizumab, an anti-CCR4 antibody, granted in Japan to treat refractory adult T-cell leukemia and lymphoma. Here, we review the main achievements obtained with anti-chemokine receptor antibodies for cancer immunotherapy, including discovery and clinical studies, proposed mechanisms of action, and therapeutic applications.

Keywords: chemokine receptors, therapeutic antibodies, clinical trials, immunotherapy, cancer

\section{INTRODUCTION}

Cancer treatment is expanding from non-specific cytotoxic chemotherapies to targeted therapies. These are focused on fighting cancer cells, modifying the tumor microenvironment, or enhancing anti-tumor immunity (1-3). Malignant and stromal cells secrete a variety of proteins, including matrix components, proteolytic enzymes, growth factors, pro-inflammatory cytokines, and chemokines $(2,4)$. Among them, tumor-associated chemokines play a central role in cancer biology, favoring leukocyte infiltration, promoting tumor growth, angiogenesis, and immune evasion (5-10).

Many tumor cells over-express functional chemokine receptors, undetectable on their normal counterparts. These receptors respond to chemokine signals by promoting cell survival, proliferation, adhesion, or migration, but also direct metastasis formation on tissues or organs where the corresponding ligands are secreted (9). Since the most common cause of death in cancer patients are metastases $(11,12)$, chemokine receptors expressed on the surface of cancer cells are considered suitable targets for the generation of new anti-tumor drugs $(8,13-17)$. As a consequence, a great effort has been made in the investigation of new drugs targeting chemokine receptors for cancer treatment. The initial focus was on the development of small molecules able to inhibit chemokine receptor signaling, although with limited success $(18,19)$. Recent achievements in the use of monoclonal antibodies (mAbs) targeting a variety of molecules for the treatment of leukemia, breast cancer, colon cancer, and melanoma (20-23), have contributed to move the efforts onto targeting chemokines and their receptors toward generating specific antibodies for therapeutic purposes.

The clinical use of an anti-chemokine receptor mAb, mogamulizumab, specific for the $\mathrm{C}-\mathrm{C}$ chemokine receptor type 4 (CCR4) has been granted in Japan for the immunotherapy of patients with relapsed or refractory CCR $4^{+}$adult T-cell leukemia (ATL) (24). This antibody is currently in phase II and III clinical trials in Europe and the USA for the treatment of patients with ATL, cutaneous T-cell lymphoma (CTCL), or peripheral Tcell lymphoma (PTCL) $(24,25)$. In addition, antibodies specific for the CCR2 and CXCR4 receptors are also being evaluated in clinical trials, while antibodies against many other chemokine receptors have shown effectiveness in different xenograft models of cancer (26-38).

\section{CHEMOKINES AND THEIR RECEPTORS IN CANCER}

Chemokines are a family of small chemotactic cytokines, with 44 members in humans, which generate soluble or immobilized gradients that direct the movement of cells $(39,40)$. Chemokines, by controlling leukocyte trafficking and recruitment, play a central role in homeostasis and the maintenance of innate and acquired immunity (41). They are essential in mammalian development and organogenesis, and like other cytokines stimulate cell growth, differentiation, and activation (16). Chemokines are subdivided in four major groups, namely CX3C, CXC, CC, and C, based on the number and spacing of conserved cysteine residues on 
their N-terminus $(39,42)$. These proteins are functionally known as "inflammatory" or "homeostatic," based on whether they are released upon inflammatory stimuli or constitutively secreted by cells located in lymphoid organs, respectively (43).

The biological effects of chemokines are exerted through their interaction(s) with specific surface receptors (chemokine receptors), structurally belonging to the seven transmembrane domain G protein-coupled receptor superfamily (GPCR). The chemokine receptor family contains 24 members in humans and can be subdivided, based on the class of chemokines they bind, into four subfamilies (CX3CR, CXCR, CCR, and XCR) all of them activating $\mathrm{G}$ proteins, and one subfamily (ACKR), containing 6 atypical receptors, unable to activate $\mathrm{G}$ proteins upon ligand binding (39, 44 ). It is worth to note that the chemokine/chemokine receptor system has redundancy, since some particular chemokines are able to bind to multiple receptors, and vice versa (41).

Chemokines and their receptors have been implicated in the pathogenesis of many inflammatory and infectious diseases including rheumatoid arthritis, multiple sclerosis, asthma, atherosclerosis, malaria, and AIDS $(15,16,45,46)$, but also in cancer $(5$, 47). Expression levels of chemokines and their receptors are often deregulated in malignant cells, due, for example, to inactivation of tumor suppressor genes, constitutive activation of oncogenes, or altered expression of transcription factors $(8,48-50)$.

Expression of chemokines and their receptors play a dual role in tumorigenicity. On the one hand, chemokines secreted by either the cancer-initiating cells or the normal cells surrounding them can help limiting tumor development by increasing leukocyte migration toward the site, and inducing long-term anti-tumor immunity. On the other hand, they may facilitate survival, proliferation, and metastatic potential of tumor cells $(6,10,51-54)$. The initially secreted chemokines at the tumor site play a key role defining the composition of the tissue stroma and recruiting tumor infiltrating leukocytes bearing specific chemokine receptors (CXCR1, CXCR2, CCR2, CCR4, or CCR5, among others) (7). Therefore, many chemokines are pro-inflammatory for most tumors (4) and have key functions in tumor angiogenesis $(55,56)$. For example, CXCL12 (SDF-1), the only known ligand for CXCR4, is a potent endothelial cell chemoattractant $(57,58)$.

Tumor cells are able to hijack the chemokine receptor/chemokine system on their own benefit. Strikingly, they "convert" infiltrating leukocytes into immuno-tolerant allies (59-61), since they are able to (i) attract suppressor T-cells and neutrophils (62-65), (ii) hijack immature dendritic cells, avoiding their migration toward the lymph nodes and therefore antigen presentation, favoring a tolerogenic profile (66), and (iii) participate in the recruitment and induction of myeloid-derived suppressor cells (67).

The most frequently over-expressed chemokine receptor in malignant cells is CXCR4 (68). It is present in over 23 different types of human cancer, including those with the highest incidence, such as lung, brain, prostate, breast, pancreas, ovarian, colorectal, leukemia, and melanomas (63). CXCR4 expression on malignant cells correlates with cell survival, tumor growth, angiogenesis, higher metastatic potential, and resistance to therapeutic agents (35, 69-76). Its ligand, CXCL12, is secreted in large amounts by bone marrow, lymph node, liver, and lung cells.
CXCR4 and CXCL12 can be used to exemplify the complexity of the chemokine/chemokine receptor networks in cancer. Unlike other chemokine receptors that have several ligands, it was originally thought that CXCL12 was the unique ligand for CXCR4 and that it was unable to bind any other receptor. In 2005, it was reported that CXCL12 was also able to bind ACKR3 (formerly CXCR7) with 10 times higher affinity (77-80). ACKR3 has two ligands CXCL12 and CXCL11. This receptor, in addition to important roles in embryonic development and cardiovascular functions $(79,81,82)$, also participates in breast and lung tumorigenesis and metastasis (78). The complexity of this network is even higher since the ACKR3 ligand CXCL11 is also shared by CXCR3, a chemokine receptor with two isoforms (A and B), over-expressed in many tumors, and able to bind other ligands (CXCL9 or CXCL10) (83). Altered CXCR3 isoform expression regulates cancer cell migration and invasion (84). Indeed, CXCL11 promotes proliferative signals through binding to CXCR3-A or ACKR3, whereas binding to CXCR3-B results in growth inhibitory functions (85). The complexity of several ligands being able to bind different receptors or different isoforms of a given receptor, having different outcomes (proliferation vs. growth inhibition), should be taken into account on any pharmacological intervention.

There is broad evidence indicating that the expression of a determined chemokine receptor by a tumor preferentially directs its metastasis to the organs in which the corresponding chemokine ligand is secreted $(10,86)$, some of them are detailed in Table 1. Extensive revision of the expression and actions of chemokine receptors in cancer exceeds the focus of this review and can be obtained from recent reviews in Ref. $(86,87)$.

\section{ANTIBODY-BASED DRUGS FOR CANCER THERAPY}

Monoclonal antibodies are relatively large molecules with clear advantages for their use as therapeutic drugs. These are related to their long half-life in blood, their ability to establish specific and high affinity interactions with other molecules or with immune system cells, together with their relatively low toxicity (207-210). Drugs based on mAbs are, however, more difficult and expensive to develop and produce, and less convenient to administer than small molecule drugs. Indeed, they are able to bridge the target antigen, or cells bearing the antigen, with the innate or acquired cellular immune response (211). These characteristics, together with the development of antibody humanization techniques, phage display systems, advanced high-throughput screening methods, and transgenic mice that produce human antibodies, led to many pharmaceutical companies to invest on therapeutic mAbs. This, together with the clinical success of therapeutic antibodies during the last decade, has led to an exponential increase on the number of $\mathrm{mAbs}$ for cancer treatment. For instance, in oncology, chimeric and humanized $\mathrm{mAb}$ that entered clinical studies had approval success rates four times greater than new chemical entities, including small molecule agents (211-213). The development of therapeutic antibodies is growing fast, and includes many best-selling drugs for the treatment of cancer (rituximab, bevacizumab, trastuzumab) or immunological diseases (adalimumab, infliximab) (214).

Therapeutic antibodies for cancer treatment can be classified, on the basis of the targets they are directed to, into: (i) surfaceexpressed molecules on the tumor cell; (ii) cytokines, growth 
Table 1 | Human chemokine receptors and related metastases.

\begin{tabular}{|c|c|c|c|c|}
\hline $\begin{array}{l}\text { Chemokine } \\
\text { receptor }\end{array}$ & Ligands $^{a}$ & Type of cancerb & $\begin{array}{l}\text { Metastasis } \\
\text { sites }\end{array}$ & References \\
\hline CXCR1 & CXCL5, CXCL6, CXCL8 & Melanoma, breast cancer, ovarian cancer, prostate cancer & & $(88-94)$ \\
\hline CXCR2 & $\begin{array}{l}\text { CXCL1, CXCL2, CXCL3, } \\
\text { CXCL5, CXCL6, CXCL7, } \\
\text { CXCL8 }\end{array}$ & $\begin{array}{l}\text { Melanoma, breast cancer, ovarian cancer, prostate, renal cell } \\
\text { carcinoma, pancreatic cancer, esophageal cancer }\end{array}$ & Lung & $\begin{array}{l}(33,88-92 \\
94-100)\end{array}$ \\
\hline CXCR4 & CXCL12 & $\begin{array}{l}\text { Melanoma, breast cancer, ovarian cancer, prostate cancer, glioma, } \\
\text { neuroblastoma, squamous cell cancer, head and neck cancer, } \\
\text { esophageal cancer, stomach cancer, bladder cancer, pancreatic } \\
\text { cancer, colorectal cancer, renal cancer, osteosarcoma, NSCLC, } \\
\text { AML, FCCL, ALL, CLL, NHL, multiple myeloma }\end{array}$ & $\begin{array}{l}\text { Bone marrow, } \\
\text { lymph nodes, lung, } \\
\text { liver, peritoneum }\end{array}$ & $\begin{array}{l}(35,63,69,70 \\
73,86,107,110, \\
112-148)\end{array}$ \\
\hline CCR1 & $\begin{array}{l}\text { CCL3, CCL4, CCL5, } \\
\text { CCL6, CCL7, CCL8, } \\
\text { CCL13, CCL14, CCL15, } \\
\text { CCL16, CCL23 }\end{array}$ & Colorectal cancer & Liver & $(151-154)$ \\
\hline CCR2 & $\begin{array}{l}\text { CCL2, CCL5, CCL7, } \\
\text { CCL8, CCL13, CCL16 }\end{array}$ & Breast cancer, prostate cancer, multiple myeloma & Bone marrow, lung & $(155-158)$ \\
\hline CCR3 & $\begin{array}{l}\text { CCL4, CCL5, CCL7, } \\
\text { CCL11, CCL13, CCL15, } \\
\text { CCL24, CCL26, CCL28 }\end{array}$ & Renal carcinoma, CTCL & & $(159,160)$ \\
\hline CCR7 & CCL19, CCL21 & $\begin{array}{l}\text { Melanoma, breast cancer, non-small cell lung cancer, lung cancer, } \\
\text { head and neck cancer, esophageal squamous cell carcinoma, } \\
\text { stomach cancer, gastric carcinoma, colorectal cancer, B-cell } \\
\text { CLL, CLL }\end{array}$ & Lymph nodes & $\begin{array}{l}(105,113,115 \\
129,133,135 \\
136,138,141 \\
170-179)\end{array}$ \\
\hline CCR9 & CCL25 & Melanoma, breast cancer, prostate cancer, T-ALL & Small intestine & $(86,180-186)$ \\
\hline CCR10 & CCL27, CCL28 & Melanoma, CTCL & Skin & $\begin{array}{l}(136,164 \\
187-191)\end{array}$ \\
\hline CX3CR1 & CX3CL1 & Breast cancer, prostate cancer, colorectal cancer, PDAC & $\begin{array}{l}\text { Bone marrow, } \\
\text { peripheral nerves, } \\
\text { brain }\end{array}$ & $\begin{array}{l}(149,150 \\
192-200)\end{array}$ \\
\hline ACKR3 & CCL11, CCL12 & Breast cancer, NSCLC, rhabdomyosarcoma & $\begin{array}{l}\text { Lung, bone } \\
\text { marrow, liver, brain }\end{array}$ & $(201-205)$ \\
\hline ACKR6 & CCL18 & Breast cancer & Lung, liver & $(206)$ \\
\hline
\end{tabular}

${ }^{a}$ Chemokine receptors and their corresponding chemokines, following the updated nomenclature in Bachelerie et al. (39).

${ }^{b}$ Types of cancer that over-express certain chemokine receptors.

ALL, acute lymphoblastic leukemia; AML, acute myeloid leukemia; ATL, adult T-cell leukemia; ATLL, adult T-cell leukemia/lymphoma; CLL, chronic lymphocytic leukemia; CTCL, cutaneous T-cell lymphoma; FCCL, follicular center lymphoma; NHL, non-Hodgkin's lymphoma; NSCLC, non-small cell lung cancer; PDAC, pancreatic ductal adenocarcinoma; PTCL, peripheral T-cell lymphoma; T-ALL, T-cell acute lymphoblastic leukemia. 
factors, surface receptors, or other molecules required for tumor and/or stroma proliferation or survival; and (iii) immune cell surface molecules that regulate tumor cell recognition and elimination. Conversely, on the basis of their mechanisms of action, they would be classified as mAbs that kill tumor cells through: (i) direct effects (host independent) (i.e., inhibiting receptorligand binding, and/or activating intracellular signaling); (ii) indirect effects (host dependent) modulating the immune response [i.e., antibody-dependent cell-mediated cytotoxicity (ADCC), complement-dependent cytotoxicity (CDC), antibody-dependent phagocytosis (ADP), etc.]; (iii) being used as molecular carriers, specifically delivering cytotoxic agents, toxins, or radio-isotopes, to target malignant cells (209); and (iv) targeting regulatory molecules on host immune system cells. Therapeutic mAbs often exert their anti-tumoral functions simultaneously using several of these mechanisms of action (29).

During the last years, a broad effort has been centered on targeting regulatory molecules from the host immune system that act as "immune checkpoints" with mAbs. Examples are ipilimumab, a $\mathrm{mAb}$ directed against the receptor cytotoxic $\mathrm{T}$ lymphocyteassociated antigen 4 (CTLA-4), or pembrolizumab (MK-3475), a mAb against the programed cell death protein-1 (PD-1), used for the treatment of metastatic melanomas (215). These mAbs inhibit the negative regulatory signals triggered by CTLA-4 or PD-1, enhancing T-cell responses against the tumor (215-218). Other mAbs, recognizing antigens on the antigen presenting cells, such as an agonist $\mathrm{mAb}$ against the stimulatory protein CD40 have also been postulated to harbor therapeutic effects against tumors $(218,219)$.

Antibodies have been generated against chemokines and their receptors. Since chemokine receptors have seven domains embedded in the cell membrane, their solubilization for obtaining the required amounts in the native conformation and the correct orientation for their use as immunogens is extremely difficult (220). These characteristics, together with their multiple posttranslational modifications, low cell surface expression levels and lack of stability of their native conformations, make it particularly challenging to generate antibodies against them. Synthetic peptides had been used as immunogens, although this approach usually generates mAbs with low affinity and poor antagonistic effects $(221,222)$. The development of sophisticated strategies that preserve the protein native conformation during purification, along with advances in the synthesis of peptides with predesigned structures, genetic immunization techniques, production of chemokine receptor-containing liposomes or lipoparticles, or over-expression of receptors in viral particles, enabled the generation of antibodies with higher affinities and/or able to function as strong antagonists (220). The expected in vivo efficacy of mAbs anti-chemokine receptors is higher than those against chemokines, since a cell surface-restricted receptor molecule is more efficiently targeted than delocalized secreted chemokines $(220,223)$. In addition, chemokine receptor targeting offers the possibility not only of blocking the signaling by preventing ligand binding to its receptor but also of tagging the tumor cells with the antibody, to trigger the host immune response against them.

Anti-chemokine receptor antibodies have been evaluated for the treatment of inflammatory and infectious diseases, including
anti-CCR2 for rheumatoid arthritis and atherosclerosis (224); CCR3 and CCR4 for asthma and pulmonary inflammation (225228); CXCR4 and CCR5 for HIV infections (229, 230); and CCR7 for pulmonary fibrosis (231). However, in the following paragraphs, we will only focus on their potential as anti-cancer drugs.

\section{CHEMOKINE RECEPTORS WITH ANTIBODIES IN CLINICAL TRIALS FOR CANCER TREATMENT}

Monoclonal antibodies against CXCR4, CCR2, and CCR4 have entered clinical trials for cancer therapy. A list of trials with these antibodies is shown in Table 2, and antibodies against each of these receptors and their potential in cancer therapy are described below.

\section{CXCR4}

As demonstrated by a plethora of publications, CXCR4 has a key role in fundamental aspects of cancer, including proliferation, migration, invasion, and angiogenesis (35, 69-76, 234-237), leading to a number of programs to develop therapeutic anti-CXCR4 antibodies. The most advanced candidate is MDX-1338, an antiCXCR4 mAb also known as BMS-936564 (owned by Bristol-Myers Squibb Co.). It was raised on human Ig transgenic mice immunized with human CXCR4-transfected mouse cells (232). This antibody (IgG4) blocks CXCL12 binding to its receptor with high affinity, and inhibits CXCL12-induced migration and calcium flux. MDX-1338 shows anti-tumoral activity in xenografts of acute myeloid leukemia (AML), non-Hodgkin lymphoma (NHL), and multiple myeloma. In vitro assays showed that the antibody triggers tumor cell apoptosis, allowing to propose it as one of the mechanisms of tumor growth inhibition (232).

MDX-1338 is currently undergoing two Phase I studies. The first-in-human study (ClinicalTrials.gov Identifier: NCT01120457) started in 2010 and was planned to be accomplished by the end of 2014 and to enroll up to 82 patients. This anti-CXCR4 $\mathrm{mAb}$ is being evaluated as a monotherapy and combined with chemotherapy to treat patients with relapsed/refractory AML, diffuse large B-cell leukemia, chronic lymphocytic leukemia (CLL), or follicular lymphoma. The aim of the trial is to determine the safety, tolerability, maximum tolerated dose, preliminary pharmacodynamics, and efficacy. A second Phase I trial (NCT01359657) started in 2011 to determine safety and tolerability of MDX-1338 as monotherapy or in combination with lenalidomide/dexamethasone or bortezomib/dexamethasone in subjects with relapsed/refractory multiple myeloma. This study is planned to enroll up to 64 patients and be finished in 2015 .

Other antibody-derived molecules targeting CXCR4 are being evaluated in clinical trials. This is the case for ALX-0651 (owned by Ablynx, Belgium), a biparatopic anti-CXCR4 nanobody, directed against two different epitopes of CXCR4 (32). Nanobodies are single-domain proteins, derived from the antibody-binding fragment of camelid antibodies. Their immunoglobulins are devoid of light chains and possess only heavy-chains. Nanobodies have the advantages of their relative small size $(12-15 \mathrm{kDa})$ and high solubility, which allows them to cross tissue barriers easily than mammalian immunoglobulins (with a 10-fold higher M.W.).ALX-0651 effectively mobilizes hematopoietic stem cells in a pre-clinical 
Table 2 | Anti-chemokine receptors antibodies for cancer therapy in clinical trials

\begin{tabular}{|c|c|c|c|c|c|c|c|}
\hline $\begin{array}{l}\text { mAb name; mAb class; } \\
\text { mAb actions }\end{array}$ & $\begin{array}{l}\text { Chemokine } \\
\text { receptor }\end{array}$ & $\begin{array}{l}\text { Clinical trial identifier; } \\
\text { start date; intervention }\end{array}$ & Phase & Condition & Country & $\begin{array}{l}\text { Status; } \\
\text { completion } \\
\text { date }\end{array}$ & $\begin{array}{l}\text { Company/ } \\
\text { sponsor }\end{array}$ \\
\hline \multirow[t]{2}{*}{$\begin{array}{l}\text { MDX-1338 (232), } \\
\text { BMS-9365649, } \\
\text { ulocuplumab; fully human, } \\
\text { IgG4; neutralization, } \\
\text { apoptosis induction }\end{array}$} & \multirow[t]{2}{*}{ CXCR4 } & $\begin{array}{l}\text { NCT01359657a; } 2011 \text {; } \\
\text { monotherapy or combined with } \\
\text { lenalidomide, dexamethasone, } \\
\text { or bortezomib }\end{array}$ & 1 & Multiple myeloma & United States & $\begin{array}{l}\text { Active, not } \\
\text { recruiting }\end{array}$ & $\begin{array}{l}\text { Bristol-Myers } \\
\text { Squibb }\end{array}$ \\
\hline & & $\begin{array}{l}\text { NCT01120457a ; 2010; } \\
\text { monotherapy }\end{array}$ & 1 & $\begin{array}{l}\text { AML, DLBCL, CLL, follicular } \\
\text { lymphoma }\end{array}$ & United States & $\begin{array}{l}\text { Active, not } \\
\text { recruiting }\end{array}$ & $\begin{array}{l}\text { Bristol-Myers } \\
\text { Squibb }\end{array}$ \\
\hline $\begin{array}{l}\text { MLN1202 (224); } \\
\text { humanized, IgG1; } \\
\text { neutralization }\end{array}$ & CCR2 & $\begin{array}{l}\text { NCT01015560a; } 2010 ; \\
\text { monotherapy }\end{array}$ & ॥ & Bone metastases & United States & $\begin{array}{l}\text { Completed } \\
2012\end{array}$ & $\begin{array}{l}\text { Millenium-Takeda/ } \\
\text { Southwestern } \\
\text { Oncology Group }\end{array}$ \\
\hline \multirow[t]{9}{*}{$\begin{array}{l}\text { KW-0761 (233), AMG 761, } \\
\text { mogamulizumab; } \\
\text { humanized, IgG1; ADCC }\end{array}$} & \multirow[t]{9}{*}{ CCR4 } & $\begin{array}{l}\text { UMIN000010050 } \\
\text { NCT01929486 } ; 2013 ; \\
\text { monotherapy }\end{array}$ & $\mathrm{la} / \mathrm{lb}$ & $\begin{array}{l}\text { Advanced or recurrent CCR4- } \\
\text { cancer (effect of Treg cell } \\
\text { depletion) }\end{array}$ & Japan & Recruiting & $\begin{array}{l}\text { Kyowa Hakko Kirin } \\
\text { Pharma, Inc. }\end{array}$ \\
\hline & & $\begin{array}{l}\text { UMIN000013294 } ; 2013 ; \\
\text { prognostic study of patient who } \\
\text { completed Study } \\
\text { NCT01173887a }\end{array}$ & II & $\mathrm{CCR} 4^{+}$ATLL & Japan & $\begin{array}{l}\text { Not longer } \\
\text { recruiting }\end{array}$ & $\begin{array}{l}\text { Kyowa Hakko Kirin } \\
\text { Pharma, Inc. }\end{array}$ \\
\hline & & $\begin{array}{l}\text { NCT01626664 ; } 2012 ; \text { KW0761 } \\
\text { or investigator's choice }\end{array}$ & ॥ & Relapsed or refractory ATLL & $\begin{array}{l}\text { United States, Belgium, Brazil, } \\
\text { France, Peru, United Kingdom }\end{array}$ & Recruiting & $\begin{array}{l}\text { Kyowa Hakko Kirin } \\
\text { Pharma, Inc. }\end{array}$ \\
\hline & & $\begin{array}{l}\text { NCT01728805a; } 2012 ; \\
\text { monotherapy vs. vorinostat }\end{array}$ & III & Relapsed or refractory CTCL & $\begin{array}{l}\text { United States, Australia, Denmark, } \\
\text { France, Germany, Italy, Japan, } \\
\text { Netherlands, Spain, Switzerland, } \\
\text { United Kingdom }\end{array}$ & Recruiting & $\begin{array}{l}\text { Kyowa Hakko Kirin } \\
\text { Pharma, Inc. }\end{array}$ \\
\hline & & $\begin{array}{l}\text { NCT01611142a }{ }^{\mathrm{a}} \text { 2011-004151-39c; } \\
\text { 2012; monotherapy }\end{array}$ & II & $\begin{array}{l}\text { Relapsed or refractory CCR4+ } \\
\text { PTCL }\end{array}$ & $\begin{array}{l}\text { Denmark, France, Italy, Netherlands, } \\
\text { Spain, Germany, United Kingdom }\end{array}$ & $\begin{array}{l}\text { Active, not } \\
\text { recruiting }\end{array}$ & $\begin{array}{l}\text { Kyowa Hakko Kirin } \\
\text { Pharma, Inc. }\end{array}$ \\
\hline & & $\begin{array}{l}\text { NCT01173887a; } 2010 \text {; Compare } \\
\text { mLSG15+KW-0761 to mLSG15 }\end{array}$ & ॥ & Untreated CCR4 ${ }^{+}$ATLL & Japan & Completed & $\begin{array}{l}\text { Kyowa Hakko Kirin } \\
\text { Pharma, Inc. }\end{array}$ \\
\hline & & $\begin{array}{l}\text { NCT01226472a ; 2010; } \\
\text { monotherapy }\end{array}$ & II & $\begin{array}{l}\text { Relapsed PTCL, CTCL, including } \\
\text { mycosis fungoides and Sezary } \\
\text { Syndrome }\end{array}$ & United States & Completed & $\begin{array}{l}\text { Kyowa Hakko Kirin } \\
\text { Pharma, Inc. }\end{array}$ \\
\hline & & $\begin{array}{l}\text { NCT01192984a ; 2010; } \\
\text { monotherapy }\end{array}$ & ॥ & $\begin{array}{l}\text { Relapsed CCR4 }{ }^{+} \text {peripheral } \\
\text { T/NK-cell lymphoma }\end{array}$ & Japan & Completed & $\begin{array}{l}\text { Kyowa Hakko Kirin } \\
\text { Pharma, Inc. }\end{array}$ \\
\hline & & $\begin{array}{l}\text { NCT00920790a; 2009; } \\
\text { monotherapy }\end{array}$ & ॥ & Relapsed CCR4 ${ }^{+} \mathrm{ATLL}$ & Japan & Completed & $\begin{array}{l}\text { Kyowa Hakko Kirin } \\
\text { Pharma, Inc. }\end{array}$ \\
\hline
\end{tabular}




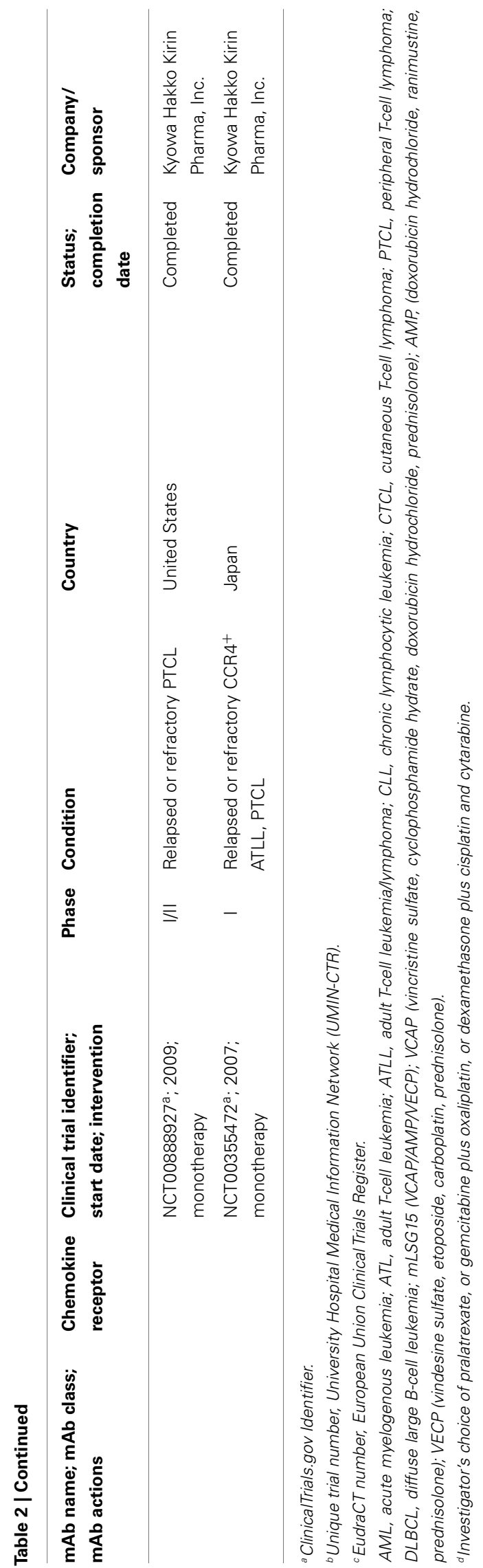

cynomolgus monkey model (32). A Phase I study of safety and effectiveness for this nanobody in healthy volunteers started in 2011 (NCT01374503), but no results have yet been reported.

In addition, many pre-clinical reports have demonstrated the in vivo relevance of CXCR4 as a target for cancer therapy. An early report by Müller and co-workers demonstrated a key role for chemokine receptors in metastasis, linking the expression of CXCR4 in breast carcinomas with their ability to generate regional lymph node and lung metastases (35). These data were supported by experiments in which a neutralizing anti-human CXCR4 antibody (clone 44717.111) led to a significant decrease in lung, inguinal, and axillary lymph node metastases. This work highlighted that chemokine interactions with chemokine receptors might turn to be crucial for breast cancer metastasis, showing that antibodies anti-CXCR4 may be useful to interfere with tumor progression and metastasis. Subsequently, similar results were obtained treating xenografts of a human NHL (26) and of a primary human AML (38) with another anti-human CXCR4 antibody (clone 12G5). In both models, a significant reduction on tumor progression was reported. In endometrial cancer xenografts, treatment with $12 \mathrm{G} 5 \mathrm{mAb}$ led to a complete inhibition of spontaneous metastases in liver and lung, and a 28 -fold decrease in metastatic index in the peritoneum (30). Interestingly, on an intratibial human osteosarcoma xenograft model, 12G5 $\mathrm{mAb}$ reduced metastatic spread to the lung (27).

\section{CCR2}

CCR2 expression in tumor cells facilitates prostate and breast cancer metastases to the bone, where its ligand CCL2 is expressed $(155,238)$. Prostate cancer patients with bone metastases had higher CCL2 serum levels than patients with localized tumors (155). In vitro and in vivo experiments using CCR2 or CCL2 knocked down prostate cancer cells demonstrated that these proteins promote prostate cancer growth in bone (238). Similarly, breast cancer metastasis to bone and lung is facilitated by CCL2 interaction with the CCR2 ${ }^{+}$stromal cells of monocytic origin, including macrophages and pre-osteoclasts (238). MLN1202, a humanized, neutralizing anti-CCR2 mAb (224) (developed by Millenium Pharmaceuticals Inc., currently Takeda Pharmaceuticals Co.) went through a Phase II clinical trial for the treatment of bone metastases (NCT01015560). MLN1202 was administered to 44 patients with bone metastasis to address its effect on tumor cell proliferation, monocyte/macrophage trafficking, and osteoclast maturation. Forty-one out of 43 eligible patients completed this study, with 7\% having serious adverse events. The concentration in urine of the $n$-telopeptide, a biomarker to measure bone turnover rates, decreased in $14 \%$ of the patients after 43 days of MLN 1202 treatment, suggesting a positive effect of the antibody in these patients.

\section{CCR4}

CCR4 is a chemokine receptor predominantly expressed on type 2 $\mathrm{T}$ helper cells (Th2), Foxp3 ${ }^{+}$regulatory T-cells (Treg), a subset of $\mathrm{CD}^{+}$Th17 cells, and skin-homing T-cells positive for cutaneous lymphocyte antigen (CLA) (239-243). This receptor binds two ligands, CCL17 (formerly TARC) and CCL22 (formerly MDC), and has been implicated in the pathology of inflammatory diseases and 
cancer, being over-expressed on many malignant ATL, CTCL, and PTCL cells (161-163).

The antibody KW-0761 (mogamulizumab), a derivative of the mouse KM2160 mAb, is a humanized defucosylated IgG1 mAb targeting CCR4 (developed by Kyowa Hakko Kirin Co.) (233). KM2160, its chimera KM2760 and the humanized version KW0761 recognize the N-terminal region of human CCR4 $(163,233$, 244). They neither block the interaction between CCR4 and their ligands nor inhibit CCR4 signaling (233). Defucosylation increases Fc-binding to the Fc $\gamma$ receptors expressed on cytotoxic cells, activating them for tumor cell killing (245). In fact, KM2760 showed potent anti-tumor activity in mouse xenografts of CCR $4^{+}$cell lines derived from patients diagnosed of ATL, Hodgkin lymphoma, or CTCL $(242,246,247)$. In addition, this mAb showed enhanced ADCC against primary CCR4 ${ }^{+}$ATL cells both in vitro and in vivo in an autologous setting $(163,233,246)$. A phase I clinical trial of KW-0761 for patients with relapsed CCR4 ${ }^{+}$PTCL or ATL was the first one to examine the safety and efficacy of a new generation defucosylated therapeutic antibodies for cancer treatment (NCT00355472) (248).

KW-0761 was approved for therapeutic use in Japan for relapsed or refractory CCR4 ${ }^{+}$ATL in 2012, and for relapsed or refractory CCR4 ${ }^{+}$PTCL or CTCL in 2014, representing the first approved antibody drug against GPCR receptors being used for cancer therapy. In other countries, there are several clinical trials currently under way, such as a Phase II (NCT01611142) for patients with relapsed or refractory PTCL, and a Phase III for the comparison of progression-free survival, after treatment with either KW-0761 or vorinostat (a chemical inhibitor of histone deacetylases), on patients with previously treated CTCL (NCT01728805). Despite the positive effects of mogamulizumab in resistant/refractory ATL, PTCL, or CTCL, the application for its use in untreated CCR $4^{+}$ATL was withdrawn by the company, on February 2014.

A therapeutic potential for mogamulizumab has been suggested against Epstein-Barr virus (EBV)-associated T- and NK-cell lymphoproliferative diseases, which can be refractory to conventional chemotherapies (249). In particular, since this mAb induced $\mathrm{ADCC}$ activity against CCR4 ${ }^{+} \mathrm{EBV}^{+}-\mathrm{T}$ and $-\mathrm{NK}$-cell lines, and inhibited the growth of $\mathrm{EBV}^{+}$NK-cell lymphomas in xenografts (249).

It is known that Treg cells can facilitate tumor cell evasion from immune surveillance (250). Since CCR4 is expressed on Treg cells, it was conceivable that treatments targeting CCR4 might affect Treg cells. On CTCL patients, a single dose of mogamulizumab has been shown to reduce the fraction of CCR4 ${ }^{+}$malignant T-cells, with a concomitant reduction of CCR4 ${ }^{+}$Treg cells. Interestingly, the reduction of Treg cells may, in turn, improve the immune profiles of these patients (251). KM2760 has also been used, in cotreatment with NK cells, for the in vitro elimination of Treg cells (252). A patient treated with mogamulizumab suffered serious adverse reactions and the Stevens-Johnson syndrome (a milder form of toxic epidermal necrolysis), probably due to a significant reduction of its Treg cells (253). A positive interpretation of these results would suggest, however, that anti-CCR4 mAbs could be used on CCR $4^{-}$tumors to deplete Treg cells from circulation and infiltrating the tumor mass. Indeed, a phase I clinical trial of mogamulizumab for CCR4- solid cancers (UMIN000010050), specifically aiming to deplete Treg cells is currently under way (253). Other adverse effects of mogamulizumab include cutaneous reactions that improve over time (254), the reactivation of hepatitis B virus (255), or diffuse panbronchiolitis (256).

There are other anti-CCR4 mAbs being screened on discovery or pre-clinical phases. Among them, mAb1567 is a humanized neutralizing anti-CCR4 antibody that exhibits potent anti-CCR4 ${ }^{+}$ CTCL tumor activity in xenografts, where it displays in vitro CDC and neutrophil-mediated ADCC. mAb1567 also exerts in vitro human NK cell-mediated ADCC (29). In addition, SCID-beige mice expressing an adenovirus construct derived from mAb1567 allowed an effective in vivo treatment of CTCL (257). Furthermore, $\mathrm{mAb} 2-3$, an affinity-optimized variant of the humanized $\mathrm{mAb} 1567$, has been selected for further pre-clinical development (29). Human anti-CCR4 antibodies, generated by phage display (17G and 9E), also show in vitro efficient killing of CCR4 ${ }^{+}$ tumor cells via ADCC and phagocytosis, and improved survival in xenografts (31).

\section{CHEMOKINE RECEPTORS WITH ANTIBODIES IN DISCOVERY OR PRE-CLINICAL ASSAYS FOR CANCER TREATMENT CXCR2}

CXCR2 and its ligands, the chemokines CXCL1, CXCL2, CXCL3, CXCL5, CXCL6, CXCL7, and CXCL8, are expressed by a wide variety of human cancer types $(41,258)$. CXCR2 is a potent protumorigenic receptor that mediates the recruitment of immunosuppressive leukocytes into tissues, in particular of neutrophils (259). Immunopathological analyses demonstrated the expression of high levels of CXCR2 and its ligand CXCL5 in pancreatic tumors (33). Thus, it was conceivable that treatment with antiCXCR2 antibodies would inhibit leukocyte infiltration and their pro-tumoral activities. Indeed, treatment with neutralizing antimouse CXCR2 antibodies of human pancreatic tumors growing as xenografts displayed reduced tumor volumes, decreased proliferation indexes, and microvessel densities $(33,260)$. The pancreatic tumor cell line used in that model was devoid of CXCR2 expression (261). CXCR2 can also be expressed on endothelial cells (262), where it can mediate angiogenesis (263). These data, together with a series of in vitro assays demonstrating an antiangiogenic role for antagonist anti-CXCR2 mAbs in endothelial cells (260), suggested that inhibition of tumor growth in the xenograft model was due to angiogenesis inhibition mediated by these antibodies.

\section{CXCR5}

A different approach was used to target CXCR5. In this case, a bispecific $\mathrm{Ab}$, containing paratopes recognizing CXCR5 on the one side and the CD3-T-cell co-receptor on the other, was used (36). With this tool, the authors were able to bring together the tumor cell, recognized with the anti-CXCR5 paratope, with a T lymphocyte, recognized with the anti-CD3 paratope, maintaining the ability of the antibody to bind cells of the innate immune response through the Fc region, potentiating in this way the anti-tumoral response (36). This bispecific antibody was highly efficient lysing tumor cells at low concentrations not only in vitro but also in vivo on xenograft models of B-cell lymphoma (36). 


\section{CCR7}

In subcutaneously injected human mantle cell lymphoma (MCL) cells on mice, anti-CCR7 treatment caused a significant delay on tumor growth and metastasis generation. It also hindered lymphoma cell dissemination in intravenous injections (37). The data obtained were compatible with both decreased infiltration of MCL cells into different tissues and the induction of anti-MCL cell cytotoxicity in mice. Anti-CCR7 therapy might be indicated for patients carrying CCR7 ${ }^{+}$B-cell NHL or CLL (37).

\section{CCR9}

We have reported the generation and characterization of $91 \mathrm{R}$, a mouse anti-human CCR9 $\mathrm{mAb}$ able to reduce $85 \%$ human $\mathrm{T}$ lymphoblastic cell tumors on mice. Tumor size reduction was concomitant with an increased apoptotic tumor cell fraction and tumor necrotic areas, as well as decreased fraction of proliferating cells and tumor vascularization. It is likely that CDC or ADCC represent the in vivo mechanisms of action of this mAb (28). These results suggest that CCR9-expressing tumors, such as acute and chronic T-cell lineage leukemia (180), prostate cancer (181), breast cancer (182), and melanomas (183), can potentially be targeted with this $\mathrm{mAb}$.

\section{ACKR3 (FORMERLY CXCR7)}

Anti-ACKR3 nanobodies inhibited tumor growth of ACKR3 ${ }^{+}$ head and neck cancer cells, reducing expression of the endothelial cell marker CD31 in the tumors growing as xenografts. These data were corroborated by in vitro analyses demonstrating that anti-ACKR3 nanobodies rather than affecting cell cycle progression, reduced the secretion of the angiogenic chemokine CXCL1 by the tumor cells, suggesting that anti-ACKR3 nanobodies could inhibit tumor vascularization. This work proposes anti-ACKR3 therapies as potential novel treatments against ACKR3 ${ }^{+}$head and neck cancer (34).

The antibodies described so far are representative of the use of anti-chemokine receptor antibodies for cancer treatment, but they represent only the tip of the iceberg, since many companies describe in their web pages, or have already presented in specialized meetings their efforts for developing new antibodies. Some of these antibodies are AT008 (anti-CCR4) and AT009 (anti-CXCR4) from Affitech; anti-CXCR5, anti-CCR2, and antiCXCR3 from Sorrento Therapeutics Inc.; anti-CXCR4 (515H7) from Pierre Fabre (264); and anti-CXCR4 (CX-02 and CX-05) from NorthWest Biotherapeutics Inc. (265).

\section{CONCLUSION AND PERSPECTIVES}

Chemokines and their receptors, in addition to their role on physiological responses, directing the cells toward specific sites, allowing lymphocyte maturation, survival, proliferation, and migration, they play a key role in cancer initiation, angiogenesis, tumor growth, progression, and metastasis. The over-expression by many tumors of chemokine receptors turns them and their ligands into clear targets for cancer therapy, on the initial assumption that inhibition of chemokine signaling might block tumor progression and/or metastasis.

The development of small molecules able to inhibit chemokine receptor signaling has shown limited success, with the exception of plerixafor (AMD3100), which by blocking binding of CXCL12 to CXCR4 mobilizes CXCR4 ${ }^{+}$cells, including CXCR4 ${ }^{+}$tumor cells, from the bone marrow to circulation $(266,267)$. Plerixafor enhances sensitivity of tumor cells to cytotoxic agents by disrupting interaction with the tumor microenvironment (268271). Since therapeutic mAbs have provided clinical benefits to cancer patients during the last decade, therapeutic antibodies against chemokine receptors seemed a good alternative. The recent technological advances allowed the generation of highly specific, high affinity antibodies against these receptors that are currently entering the clinics.

This "theoretical" view suggesting that anti-chemokine receptor mAbs might represent an efficient way to treat cancer was fully supported by the recent approval in Japan of mogamulizumab for the treatment of ATL. It is so far the only anti-GPCR therapeutic antibody in the market and represents the proof-of-principle for the therapeutic use of mAbs targeting GPCRs, as on chemokine receptors, leading to clinical benefits on cancer patients.

Chemokine receptors are expressed, in addition to endothelial cells, on the tumor and on cells from the immune system, responsible for defending from the tumor. Therefore, any drug or antibody targeting a given chemokine receptor will act on both the tumor and immune system cells expressing it. In the case of mogamulizumab, raised against CCR4, it should be noted that there is only a fraction of T lymphocytes (within the Th2, Treg, and Th17 phenotypes) that are $\mathrm{CCR} 4^{+}$, representing the few non-tumoral targets for this antibody. Since the phenotypes affected include Treg and Th17 cells, their elimination would become advantageous for treating the tumor, as the immunosuppressive responses would be reduced. Treatment with antibodies against other chemokine receptors such as CXCR4 or CCR7 might have a broad effect on the host immune response, since there is a large fraction of leukocytes expressing them. This effect is not necessarily beneficial in terms of reducing tumor size.

These data raise the question whether other anti-chemokine receptors can be safely used as targets for tumor treatment. In particular, it should be determined, for each chemokine receptor, whether there are therapeutic doses of an antibody able to effectively kill tumor cells or cells favoring tumor growth, while not affecting the normal cells from the immune system expressing that particular receptor. In other words, the aim is to find the therapeutic window where tumor cells are safely destroyed whereas the immune cells are not. This can be exemplified with data on CCR2 ${ }^{+}$tumor infiltrating cells, where if the infiltrating cells are macrophages supporting the metastatic dissemination of malignant cells, the anti-CCR2 treatment may be effective. Conversely, if the infiltrating cells are $\mathrm{CD}^{+}$and $\gamma \delta$ effector T-cells that enhance immuno-surveillance by triggering Th1 responses, the treatment might turn deleterious $(272,273)$.

Thus, the complex network between chemokine receptors and their ligands, together with the simultaneous expression of a given receptor on cells of the immune system and on the tumor (including tumor cells, stroma cells, and/or tumor infiltrating cells) and the dichotomy of their responses clearly represent the lights and shadows of the potential of anti-chemokine receptor therapeutic antibodies for the treatment of tumors. The optimal situation would be to have a panel of therapeutic antibodies against different 
chemokine receptors. These antibodies could be used, depending on the tumor phenotype, in particular combinations (personalized medicine) at relatively low doses for each one of them, minimizing the probability of affecting the normal cells.

\section{ACKNOWLEDGMENTS}

We thank Drs. Inés Antón and M. Teresa Martín for critical reading of the manuscript and for helpful suggestions. The work in the authors' laboratory was supported by grants from the Instituto de Salud Carlos III (PI10/00594 and PI14/00703) and the CSIC (201320E109 and 201420E109), Ministerio de Economía y Competitividad to Leonor Kremer.

\section{REFERENCES}

1. Burger JA, Gribben JG. The microenvironment in chronic lymphocytic leukemia (CLL) and other B cell malignancies: insight into disease biology and new targeted therapies. Semin Cancer Biol (2014) 24:71-81. doi:10.1016/j. semcancer.2013.08.011

2. Liotta LA, Kohn EC. The microenvironment of the tumour-host interface. Nature (2001) 411(6835):375-9. doi:10.1038/35077241

3. Vanneman M, Dranoff G. Combining immunotherapy and targeted therapies in cancer treatment. Nat Rev Cancer (2012) 12(4):237-51. doi:10.1038/nrc3237

4. Soria G, Ben-Baruch A. The inflammatory chemokines CCL2 and CCL5 in breast cancer. Cancer Lett (2008) 267(2):271-85. doi:10.1016/j.canlet.2008. 03.018

5. Vicari AP, Caux C. Chemokines in cancer. Cytokine Growth Factor Rev (2002) 13(2):143-54. doi:10.1016/S1359-6101(01)00033-8

6. Balkwill F. Chemokine biology in cancer. Semin Immunol (2003) 15(1):49-55. doi:10.1016/S1044-5323(02)00127-6

7. Lazennec G, Richmond A. Chemokines and chemokine receptors: new insights into cancer-related inflammation. Trends Mol Med (2010) 16(3):133-44. doi:10.1016/j.molmed.2010.01.003

8. Mantovani A, Savino B, Locati M, Zammataro L, Allavena P, Bonecchi R. The chemokine system in cancer biology and therapy. Cytokine Growth Factor Rev (2010) 21(1):27-39. doi:10.1016/j.cytogfr.2009.11.007

9. Mukaida N, Baba T. Chemokines in tumor development and progression. Exp Cell Res (2012) 318(2):95-102. doi:10.1016/j.yexcr.2011.10.012

10. Sarvaiya PJ, Guo D, Ulasov I, Gabikian P, Lesniak MS. Chemokines in tumor progression and metastasis. Oncotarget (2013) 4(12):2171-85.

11. Gupta GP, Massague J. Cancer metastasis: building a framework. Cell (2006) 127(4):679-95. doi:10.1016/j.cell.2006.11.001

12. Spano D, Heck C, De Antonellis P, Christofori G, Zollo M. Molecular networks that regulate cancer metastasis. Semin Cancer Biol (2012) 22(3):234-49. doi:10.1016/j.semcancer.2012.03.006

13. Homey B, Muller A, Zlotnik A. Chemokines: agents for the immunotherapy of cancer? Nat Rev Immunol (2002) 2(3):175-84. doi:10.1038/nri748

14. Garber K. First results for agents targeting cancer-related inflammation. J Natl Cancer Inst (2009) 101(16):1110-2. doi:10.1093/jnci/djp266

15. Garin A, Proudfoot AE. Chemokines as targets for therapy. Exp Cell Res (2011) 317(5):602-12. doi:10.1016/j.yexcr.2010.12.021

16. Raman D, Sobolik-Delmaire T, Richmond A. Chemokines in health and disease. Exp Cell Res (2011) 317(5):575-89. doi:10.1016/j.yexcr.2011.01.005

17. Slettenaar VI, Wilson JL. The chemokine network: a target in cancer biology? Adv Drug Deliv Rev (2006) 58(8):962-74. doi:10.1016/j.addr.2006.03.012

18. Allegretti M, Cesta MC, Garin A, Proudfoot AE. Current status of chemokine receptor inhibitors in development. Immunol Lett (2012) 145(1-2):68-78. doi:10.1016/j.imlet.2012.04.003

19. Debnath B, Xu S, Grande F, Garofalo A, Neamati N. Small molecule inhibitors of CXCR4. Theranostics (2013) 3(1):47-75. doi:10.7150/thno.5376

20. Adler MJ, Dimitrov DS. Therapeutic antibodies against cancer. Hematol Oncol Clin North Am (2012) 26(3):447-81. doi:10.1016/j.hoc.2012.02.013

21. Ascierto PA, Addeo R, Carteni G, Daniele B, De Laurentis M, Ianniello G, et al. The role of immunotherapy in solid tumors: report from the Campania society of oncology immunotherapy (SCITO) meeting, Naples 2014. J Transl Med (2014) 12(1):291. doi:10.1186/s12967-014-0291-1
22. Jarboe J, Gupta A, Saif W. Therapeutic human monoclonal antibodies against cancer. Methods Mol Biol (2014) 1060:61-77. doi:10.1007/978-162703-586-6_4

23. Vacchelli E, Aranda F, Eggermont A, Galon J, Sautes-Fridman C, Zitvogel L, et al. Trial watch: tumor-targeting monoclonal antibodies in cancer therapy. Oncoimmunology (2014) 3(1):e27048. doi:10.4161/onci.27048

24. Yoshie O, Matsushima K. CCR4 and its ligands: from bench to bedside. Int Immunol (2015) 27(1):11-20. doi:10.1093/intimm/dxu079

25. Tobinai K, Takahashi T, Akinaga S. Targeting chemokine receptor CCR4 in adult T-cell leukemia-lymphoma and other T-cell lymphomas. Curr Hematol Malig Rep (2012) 7(3):235-40. doi:10.1007/s11899-012-0124-3

26. Bertolini F, Dell'Agnola C, Mancuso P, Rabascio C, Burlini A, Monestiroli S, et al. CXCR4 neutralization, a novel therapeutic approach for non-Hodgkin's lymphoma. Cancer Res (2002) 62(11):3106-12.

27. Brennecke P, Arlt MJ, Campanile C, Husmann K, Gvozdenovic A, Apuzzo T, et al. CXCR4 antibody treatment suppresses metastatic spread to the lung of intratibial human osteosarcoma xenografts in mice. Clin Exp Metastasis (2014) 31(3):339-49. doi:10.1007/s10585-013-9632-3

28. Chamorro S, Vela M, Franco-Villanueva A, Carramolino L, Gutierrez J, Gomez L, et al. Antitumor effects of a monoclonal antibody to human CCR9 in leukemia cell xenografts. MAbs (2014) 6(4):1000-12. doi:10.4161/ mabs. 29063

29. Chang DK, Sui J, Geng S, Muvaffak A, Bai M, Fuhlbrigge RC, et al. Humanization of an anti-CCR4 antibody that kills cutaneous T-cell lymphoma cells and abrogates suppression by T-regulatory cells. Mol Cancer Ther (2012) 11(11):2451-61. doi:10.1158/1535-7163.MCT-12-0278

30. Gelmini S, Mangoni M, Castiglione F, Beltrami C, Pieralli A, Andersson KL, et al. The CXCR4/CXCL12 axis in endometrial cancer. Clin Exp Metastasis (2009) 26(3):261-8. doi:10.1007/s10585-009-9240-4

31. Hagemann UB, Gunnarsson L, Geraudie S, Scheffler U, Griep RA, Reiersen H, et al. Fully human antagonistic antibodies against CCR4 potently inhibit cell signaling and chemotaxis. PLoS One (2014) 9(7):e103776. doi:10.1371/journal. pone. 0103776

32. Jahnichen S, Blanchetot C, Maussang D, Gonzalez-Pajuelo M, Chow KY, Bosch L, et al. CXCR4 nanobodies (VHH-based single variable domains) potently inhibit chemotaxis and HIV-1 replication and mobilize stem cells. Proc Natl Acad Sci U S A (2010) 107(47):20565-70. doi:10.1073/pnas.1012865107

33. Li A, King J, Moro A, Sugi MD, Dawson DW, Kaplan J, et al. Overexpression of CXCL5 is associated with poor survival in patients with pancreatic cancer. Am J Pathol (2011) 178(3):1340-9. doi:10.1016/j.ajpath.2010.11.058

34. Maussang D, Mujic-Delic A, Descamps FJ, Stortelers C, Vanlandschoot P, Stigter-van Walsum M, et al. Llama-derived single variable domains (nanobodies) directed against chemokine receptor CXCR7 reduce head and neck cancer cell growth in vivo. J Biol Chem (2013) 288(41):29562-72. doi:10.1074/jbc. M113.498436

35. Muller A, Homey B, Soto H, Ge N, Catron D, Buchanan ME, et al. Involvement of chemokine receptors in breast cancer metastasis. Nature (2001) 410(6824):50-6. doi:10.1038/35065016

36. Panjideh H, Muller G, Koch M, Wilde F, Scheu S, Moldenhauer G, et al. Immunotherapy of B-cell non-Hodgkin lymphoma by targeting the chemokine receptor CXCR5 in a preclinical mouse model. Int J Cancer (2014) 135(11):2623-32. doi:10.1002/ijc.28893

37. Somovilla-Crespo B, Alfonso-Perez M, Cuesta-Mateos C, Carballo-de Dios C, Beltran AE, Terron F, et al. Anti-CCR7 therapy exerts a potent anti-tumor activity in a xenograft model of human mantle cell lymphoma. J Hematol Oncol (2013) 6:89. doi:10.1186/1756-8722-6-89

38. Tavor S, Petit I, Porozov S, Avigdor A, Dar A, Leider-Trejo L, et al. CXCR4 regulates migration and development of human acute myelogenous leukemia stem cells in transplanted NOD/SCID mice. Cancer Res (2004) 64(8):2817-24. doi:10.1158/0008-5472.CAN-03-3693

39. Bachelerie F, Ben-Baruch A, Burkhardt AM, Combadiere C, Farber JM, Graham GJ, et al. International union of basic and clinical pharmacology. [corrected]. LXXXIX. Update on the extended family of chemokine receptors and introducing a new nomenclature for atypical chemokine receptors. Pharmacol Rev (2014) 66(1):1-79. doi:10.1124/pr.113.007724

40. Murphy PM, Baggiolini M, Charo IF, Hebert CA, Horuk R, Matsushima K, et al. International union of pharmacology. XXII. Nomenclature for chemokine receptors. Pharmacol Rev (2000) 52(1):145-76. 
41. Rot A, von Andrian UH. Chemokines in innate and adaptive host defense: basic chemokinese grammar for immune cells. Annu Rev Immunol (2004) 22:891-928. doi:10.1146/annurev.immunol.22.012703.104543

42. Zlotnik A, Yoshie O. Chemokines: a new classification system and their role in immunity. Immunity (2000) 12(2):121-7. doi:10.1016/S1074-7613(00) 80165-X

43. Rossi D, Zlotnik A. The biology of chemokines and their receptors. Annu Rev Immunol (2000) 18:217-42. doi:10.1146/annurev.immunol.18.1.217

44. Nibbs RJ, Graham GJ. Immune regulation by atypical chemokine receptors. Nat Rev Immunol (2013) 13(11):815-29. doi:10.1038/nri3544

45. Gerard C, Rollins BJ. Chemokines and disease. Nat Immunol (2001) 2(2):108-15. doi:10.1038/84209

46. White GE, Iqbal AJ, Greaves DR. CC chemokine receptors and chronic inflammation - therapeutic opportunities and pharmacological challenges. Pharmacol Rev (2013) 65(1):47-89. doi:10.1124/pr.111.005074

47. Zlotnik A. Chemokines in neoplastic progression. Semin Cancer Biol (2004) 14(3):181-5. doi:10.1016/j.semcancer.2003.10.004

48. Richmond A. Nf-kappa B, chemokine gene transcription and tumour growth. Nat Rev Immunol (2002) 2(9):664-74. doi:10.1038/nri887

49. Sparmann A, Bar-Sagi D. Ras-induced interleukin-8 expression plays a critical role in tumor growth and angiogenesis. Cancer Cell (2004) 6(5):447-58. doi:10.1016/j.ccr.2004.09.028

50. Borrello MG, Alberti L, Fischer A, Degl'innocenti D, Ferrario C, Gariboldi M, et al. Induction of a proinflammatory program in normal human thyrocytes by the RET/PTC1 oncogene. Proc Natl Acad Sci U S A (2005) 102(41):14825-30. doi:10.1073/pnas.0503039102

51. Barbieri F, Bajetto A, Florio T. Role of chemokine network in the development and progression of ovarian cancer: a potential novel pharmacological target. $J$ Oncol (2010) 2010:426956. doi:10.1155/2010/426956

52. Kakinuma T, Hwang ST. Chemokines, chemokine receptors, and cancer metastasis. J Leukoc Biol (2006) 79(4):639-51. doi:10.1189/jlb.1105633

53. O'Hayre M, Salanga CL, Handel TM, Allen SJ. Chemokines and cancer: migration, intracellular signalling and intercellular communication in the microenvironment. Biochem J (2008) 409(3):635-49. doi:10.1042/BJ20071493

54. Viola A, Sarukhan A, Bronte V, Molon B. The pros and cons of chemokines in tumor immunology. Trends Immunol (2012) 33(10):496-504. doi:10.1016/j.it. 2012.05.007

55. Mehrad B, Keane MP, Strieter RM. Chemokines as mediators of angiogenesis. Thromb Haemost (2007) 97(5):755-62.

56. Kiefer F, Siekmann AF. The role of chemokines and their receptors in angiogenesis. Cell Mol Life Sci (2011) 68(17):2811-30. doi:10.1007/s00018011-0677-7

57. Gupta SK, Lysko PG, Pillarisetti K, Ohlstein E, Stadel JM. Chemokine receptors in human endothelial cells. Functional expression of CXCR4 and its transcriptional regulation by inflammatory cytokines. J Biol Chem (1998) 273(7):4282-7. doi:10.1074/jbc.273.7.4282

58. Tachibana K, Hirota S, Iizasa H, Yoshida H, Kawabata K, Kataoka Y, et al. The chemokine receptor CXCR4 is essential for vascularization of the gastrointestinal tract. Nature (1998) 393(6685):591-4. doi:10.1038/31261

59. Brigati C, Noonan DM, Albini A, Benelli R. Tumors and inflammatory infiltrates: friends or foes? Clin Exp Metastasis (2002) 19(3):247-58. doi:10.1023/ A: 1015587423262

60. Sawanobori Y, Ueha S, Kurachi M, Shimaoka T, Talmadge JE, Abe J, et al. Chemokine-mediated rapid turnover of myeloid-derived suppressor cells in tumor-bearing mice. Blood (2008) 111(12):5457-66. doi:10.1182/blood-200801- 136895

61. Yang L, Huang J, Ren X, Gorska AE, Chytil A, Aakre M, et al. Abrogation of TGF beta signaling in mammary carcinomas recruits Gr-1+CD11b+ myeloid cells that promote metastasis. Cancer Cell (2008) 13(1):23-35. doi:10.1016/j. ccr.2007.12.004

62. Curiel TJ, Coukos G, Zou L, Alvarez X, Cheng P, Mottram P, et al. Specific recruitment of regulatory $\mathrm{T}$ cells in ovarian carcinoma fosters immune privilege and predicts reduced survival. Nat Med (2004) 10(9):942-9. doi:10.1038/ nm1093

63. Balkwill F. The significance of cancer cell expression of the chemokine receptor CXCR4. Semin Cancer Biol (2004) 14(3):171-9. doi:10.1016/j.semcancer.2003. 10.003
64. Facciabene A, Peng X, Hagemann IS, Balint K, Barchetti A, Wang LP, et al. Tumour hypoxia promotes tolerance and angiogenesis via CCL28 and T(reg) cells. Nature (2011) 475(7355):226-30. doi:10.1038/nature10169

65. Raccosta L, Fontana R, Maggioni D, Lanterna C, Villablanca EJ, Paniccia A, et al. The oxysterol-CXCR2 axis plays a key role in the recruitment of tumorpromoting neutrophils. J Exp Med (2013) 210(9):1711-28. doi:10.1084/jem. 20130440

66. Villablanca EJ, Raccosta L, Zhou D, Fontana R, Maggioni D, Negro A, et al. Tumor-mediated liver X receptor-alpha activation inhibits CC chemokine receptor-7 expression on dendritic cells and dampens antitumor responses. Nat Med (2010) 16(1):98-105. doi:10.1038/nm.2074

67. Shields JD, Kourtis IC, Tomei AA, Roberts JM, Swartz MA. Induction of lymphoid-like stroma and immune escape by tumors that express the chemokine CCL21. Science (2010) 328(5979):749-52. doi:10.1126/science. 1185837

68. Burger JA, Kipps TJ. CXCR4: a key receptor in the crosstalk between tumor cells and their microenvironment. Blood (2006) 107(5):1761-7. doi:10.1182/ blood-2005-08-3182

69. Murakami T, Maki W, Cardones AR, Fang H, Tun Kyi A, Nestle FO, et al. Expression of CXC chemokine receptor- 4 enhances the pulmonary metastatic potential of murine B16 melanoma cells. Cancer Res (2002) 62(24):7328-34.

70. Darash-Yahana M, Pikarsky E, Abramovitch R, Zeira E, Pal B, Karplus R, et al. Role of high expression levels of CXCR4 in tumor growth, vascularization, and metastasis. FASEB J (2004) 18(11):1240-2. doi:10.1096/fj.03-0935fje

71. Vandercappellen J, Van Damme J, Struyf S. The role of CXC chemokines and their receptors in cancer. Cancer Lett (2008) 267(2):226-44. doi:10.1016/j. canlet.2008.04.050

72. Balkwill F. Cancer and the chemokine network. Nat Rev Cancer (2004) 4(7):540-50. doi:10.1038/nrc1388

73. Li YM, Pan Y, Wei Y, Cheng X, Zhou BP, Tan M, et al. Upregulation of CXCR4 is essential for HER2-mediated tumor metastasis. Cancer Cell (2004) 6(5):459-69. doi:10.1016/j.ccr.2004.09.027

74. Smith MC, Luker KE, Garbow JR, Prior JL, Jackson E, Piwnica-Worms D, et al. CXCR4 regulates growth of both primary and metastatic breast cancer. Cancer Res (2004) 64(23):8604-12. doi:10.1158/0008-5472.CAN-04- 1844

75. Zlotnik A. New insights on the role of CXCR4 in cancer metastasis. J Pathol (2008) 215(3):211-3. doi:10.1002/path.2350

76. Furusato B, Mohamed A, Uhlen M, Rhim JS. CXCR4 and cancer. Pathol Int (2010) 60(7):497-505. doi:10.1111/j.1440-1827.2010.02548.x

77. Balabanian K, Lagane B, Infantino S, Chow KY, Harriague J, Moepps B, et al. The chemokine SDF-1/CXCL12 binds to and signals through the orphan receptor RDC1 in T lymphocytes. J Biol Chem (2005) 280(42):35760-6. doi:10.1074/jbc.M508234200

78. Burns JM, Summers BC, Wang Y, Melikian A, Berahovich R, Miao Z, et al. A novel chemokine receptor for SDF-1 and I-TAC involved in cell survival, cell adhesion, and tumor development. J Exp Med (2006) 203(9):2201-13. doi:10.1084/jem.20052144

79. Thelen M, Thelen S. CXCR7, CXCR4 and CXCL12: an eccentric trio? J Neuroimmunol (2008) 198(1-2):9-13. doi:10.1016/j.jneuroim.2008.04.020

80. Sanchez-Martin L, Sanchez-Mateos P, Cabanas C. CXCR7 impact on CXCL12 biology and disease. Trends Mol Med (2013) 19(1):12-22. doi:10.1016/j. molmed.2012.10.004

81. Gerrits H, van Ingen Schenau DS, Bakker NE, van Disseldorp AJ, Strik A, Hermens LS, et al. Early postnatal lethality and cardiovascular defects in CXCR7deficient mice. Genesis (2008) 46(5):235-45. doi:10.1002/dvg.20387

82. Naumann U, Cameroni E, Pruenster M, Mahabaleshwar H, Raz E, Zerwes HG, et al. CXCR7 functions as a scavenger for CXCL12 and CXCL11. PLoS One (2010) 5(2):e9175. doi:10.1371/journal.pone.0009175

83. Singh AK, Arya RK, Trivedi AK, Sanyal S, Baral R, Dormond O, et al. Chemokine receptor trio: CXCR3, CXCR4 and CXCR7 crosstalk via CXCL11 and CXCL12. Cytokine Growth Factor Rev (2013) 24(1):41-9. doi:10.1016/j.cytogfr. 2012.08.007

84. Wu Q, Dhir R, Wells A. Altered CXCR3 isoform expression regulates prostate cancer cell migration and invasion. Mol Cancer (2012) 11:3. doi:10.1186/14764598-11-3

85. Lasagni L, Francalanci M, Annunziato F, Lazzeri E, Giannini S, Cosmi L, et al. An alternatively spliced variant of CXCR3 mediates the inhibition of 
endothelial cell growth induced by IP-10, Mig, and I-TAC, and acts as functional receptor for platelet factor 4. J Exp Med (2003) 197(11):1537-49. doi:10.1084/jem.20021897

86. Zlotnik A, Burkhardt AM, Homey B. Homeostatic chemokine receptors and organ-specific metastasis. Nat Rev Immunol (2011) 11(9):597-606. doi:10. 1038/nri3049

87. Weitzenfeld P, Ben-Baruch A. The chemokine system, and its CCR5 and CXCR4 receptors, as potential targets for personalized therapy in cancer. Cancer Lett (2014) 352(1):36-53. doi:10.1016/j.canlet.2013.10.006

88. Miller LJ, Kurtzman SH, Wang Y, Anderson KH, Lindquist RR, Kreutzer DL. Expression of interleukin-8 receptors on tumor cells and vascular endothelial cells in human breast cancer tissue. Anticancer Res (1998) 18(1A): 77-81.

89. Murphy C, McGurk M, Pettigrew J, Santinelli A, Mazzucchelli R, Johnston PG, et al. Nonapical and cytoplasmic expression of interleukin-8, CXCR1, and CXCR2 correlates with cell proliferation and microvessel density in prostate cancer. Clin Cancer Res (2005) 11(11):4117-27. doi:10.1158/1078-0432.CCR04-1518

90. Sharma B, Singh S, Varney ML, Singh RK. Targeting CXCR1/CXCR2 receptor antagonism in malignant melanoma. Expert Opin Ther Targets (2010) 14(4):435-42. doi:10.1517/14728221003652471

91. Singh S, Nannuru KC, Sadanandam A, Varney ML, Singh RK. CXCR1 and CXCR2 enhances human melanoma tumourigenesis, growth and invasion. $\mathrm{Br}$ J Cancer (2009) 100(10):1638-46. doi:10.1038/sj.bjc.6605055

92. Singh S, Singh AP, Sharma B, Owen LB, Singh RK. CXCL8 and its cognate receptors in melanoma progression and metastasis. Future Oncol (2010) 6(1):111-6. doi: $10.2217 /$ fon. 09.128

93. Varney ML, Johansson SL, Singh RK. Distinct expression of CXCL8 and its receptors CXCR1 and CXCR2 and their association with vessel density and aggressiveness in malignant melanoma. Am J Clin Pathol (2006) 125(2):209-16. doi:10.1309/VPL5-R3JR-7F1D-6V03

94. Venkatakrishnan G, Salgia R, Groopman JE. Chemokine receptors CXCR$1 / 2$ activate mitogen-activated protein kinase via the epidermal growth factor receptor in ovarian cancer cells. J Biol Chem (2000) 275(10):6868-75. doi:10.1074/jbc.275.10.6868

95. Mestas J, Burdick MD, Reckamp K, Pantuck A, Figlin RA, Strieter RM. The role of CXCR2/CXCR2 ligand biological axis in renal cell carcinoma. J Immunol (2005) 175(8):5351-7. doi:10.4049/jimmunol.175.8.5351

96. Nannuru KC, Sharma B, Varney ML, Singh RK. Role of chemokine receptor CXCR2 expression in mammary tumor growth, angiogenesis and metastasis. $J$ Carcinog (2011) 10:40. doi:10.4103/1477-3163.92308

97. Norgauer J, Metzner B, Schraufstatter I. Expression and growth-promoting function of the IL-8 receptor beta in human melanoma cells. J Immunol (1996) 156(3):1132-7.

98. Sharma B, Nawandar DM, Nannuru KC, Varney ML, Singh RK. Targeting CXCR2 enhances chemotherapeutic response, inhibits mammary tumor growth, angiogenesis, and lung metastasis. Mol Cancer Ther (2013) 12(5):799-808. doi:10.1158/1535-7163.MCT-12-0529

99. Takamori H, Oades ZG, Hoch OC, Burger M, Schraufstatter IU. Autocrine growth effect of IL-8 and GROalpha on a human pancreatic cancer cell line, Capan-1. Pancreas (2000) 21(1):52-6. doi:10.1097/00006676-20000700000051

100. Wang B, Hendricks DT, Wamunyokoli F, Parker MI. A growth-related oncogene/CXC chemokine receptor 2 autocrine loop contributes to cellular proliferation in esophageal cancer. Cancer Res (2006) 66(6):3071-7. doi:10.1158/ 0008-5472.CAN-05-2871

101. Cambien B, Karimdjee BF, Richard-Fiardo P, Bziouech H, Barthel R, Millet $\mathrm{MA}$, et al. Organ-specific inhibition of metastatic colon carcinoma by CXCR3 antagonism. Br J Cancer (2009) 100(11):1755-64. doi:10.1038/sj.bjc.6605078

102. Jones D, Benjamin RJ, Shahsafaei A, Dorfman DM. The chemokine receptor CXCR3 is expressed in a subset of B-cell lymphomas and is a marker of B-cell chronic lymphocytic leukemia. Blood (2000) 95(2):627-32.

103. Kawada K, Hosogi H, Sonoshita M, Sakashita H, Manabe T, Shimahara Y, et al. Chemokine receptor CXCR3 promotes colon cancer metastasis to lymph nodes. Oncogene (2007) 26(32):4679-88. doi:10.1038/sj.onc.1210267

104. Kawada K, Sonoshita M, Sakashita H, Takabayashi A, Yamaoka Y, Manabe T, et al. Pivotal role of CXCR3 in melanoma cell metastasis to lymph nodes. Cancer Res (2004) 64(11):4010-7. doi:10.1158/0008-5472.CAN-03- 1757
105. Maekawa S, Iwasaki A, Shirakusa T, Kawakami T, Yanagisawa J, Tanaka T, et al. Association between the expression of chemokine receptors CCR7 and CXCR3, and lymph node metastatic potential in lung adenocarcinoma. Oncol Rep (2008) 19(6):1461-8.

106. Monteagudo C, Martin JM, Jorda E, Llombart-Bosch A. CXCR3 chemokine receptor immunoreactivity in primary cutaneous malignant melanoma: correlation with clinicopathological prognostic factors. J Clin Pathol (2007) 60(6):596-9. doi:10.1136/jcp.2005.032144

107. Murakami T, Kawada K, Iwamoto M, Akagami M, Hida K, Nakanishi Y, et al. The role of CXCR3 and CXCR4 in colorectal cancer metastasis. Int $J$ Cancer (2013) 132(2):276-87. doi:10.1002/ijc.27670

108. Pradelli E, Karimdjee-Soilihi B, Michiels JF, Ricci JE, Millet MA, Vandenbos F, et al. Antagonism of chemokine receptor CXCR3 inhibits osteosarcoma metastasis to lungs. Int J Cancer (2009) 125(11):2586-94. doi:10.1002/ijc.24665

109. Walser TC, Rifat S, Ma X, Kundu N, Ward C, Goloubeva O, et al. Antagonism of CXCR3 inhibits lung metastasis in a murine model of metastatic breast cancer. Cancer Res (2006) 66(15):7701-7. doi:10.1158/0008-5472.CAN-06-0709

110. Wu S, Gessner R, Taube T, Korte A, von Stackelberg A, Kirchner R, et al. Chemokine IL-8 and chemokine receptor CXCR3 and CXCR4 gene expression in childhood acute lymphoblastic leukemia at first relapse. J Pediatr Hematol Oncol (2006) 28(4):216-20. doi:10.1097/01.mph.0000212908.14642.a5

111. Zipin-Roitman A, Meshel T, Sagi-Assif O, Shalmon B, Avivi C, Pfeffer RM, et al. CXCL10 promotes invasion-related properties in human colorectal carcinoma cells. Cancer Res (2007) 67(7):3396-405. doi:10.1158/0008-5472.CAN06-3087

112. Akashi T, Koizumi K, Tsuneyama K, Saiki I, Takano Y, Fuse H. Chemokine receptor CXCR4 expression and prognosis in patients with metastatic prostate cancer. Cancer Sci (2008) 99(3):539-42. doi:10.1111/j.1349-7006.2007.00712.x

113. Ali S, Lazennec G. Chemokines: novel targets for breast cancer metastasis. Cancer Metastasis Rev (2007) 26(3-4):401-20. doi:10.1007/s10555-007-9073-z

114. Arya M, Patel HR, McGurk C, Tatoud R, Klocker H, Masters J, et al. The importance of the CXCL12-CXCR4 chemokine ligand-receptor interaction in prostate cancer metastasis. J Exp Ther Oncol (2004) 4(4):291-303.

115. Cabioglu N, Yazici MS, Arun B, Broglio KR, Hortobagyi GN, Price JE, et al. CCR7 and CXCR4 as novel biomarkers predicting axillary lymph node metastasis in T1 breast cancer. Clin Cancer Res (2005) 11(16):5686-93. doi:10.1158/ 1078-0432.CCR-05-0014

116. Eisenhardt A, Frey U, Tack M, Rosskopf D, Lummen G, Rubben H, et al. Expression analysis and potential functional role of the CXCR4 chemokine receptor in bladder cancer. Eur Urol (2005) 47(1):111-7. doi:10.1016/j.eururo.2004.10.001

117. Franco R, Botti G, Mascolo M, Loquercio G, Liguori G, Ilardi G, et al. CXCR4CXCL12 and VEGF correlate to uveal melanoma progression. Front Biosci (2010) 2:13-21. doi:10.2741/e60

118. Franco R, Cantile M, Scala S, Catalano E, Cerrone M, Scognamiglio G, et al. Histomorphologic parameters and CXCR4 mRNA and protein expression in sentinel node melanoma metastasis are correlated to clinical outcome. Cancer Biol Ther (2010) 9(6):423-9. doi:10.4161/cbt.9.6.10996

119. Hirata H, Hinoda Y, Kikuno N, Kawamoto K, Dahiya AV, Suehiro Y, et al. CXCL12 G801A polymorphism is a risk factor for sporadic prostate cancer susceptibility. Clin Cancer Res (2007) 13(17):5056-62. doi:10.1158/1078-0432. CCR-07-0859

120. Jiang YP, Wu XH, Shi B, Wu WX, Yin GR. Expression of chemokine CXCL12 and its receptor CXCR4 in human epithelial ovarian cancer: an independent prognostic factor for tumor progression. Gynecol Oncol (2006) 103(1):226-33. doi:10.1016/j.ygyno.2006.02.036

121. Kaifi JT, Yekebas EF, Schurr P, Obonyo D, Wachowiak R, Busch P, et al. Tumorcell homing to lymph nodes and bone marrow and CXCR4 expression in esophageal cancer. J Natl Cancer Inst (2005) 97(24):1840-7. doi:10.1093/jnci/ dji431

122. Kajiyama H, Shibata K, Terauchi M, Ino K, Nawa A, Kikkawa F. Involvement of SDF-1alpha/CXCR4 axis in the enhanced peritoneal metastasis of epithelial ovarian carcinoma. Int J Cancer (2008) 122(1):91-9. doi:10.1002/ijc.23083

123. Kang H, Watkins G, Douglas-Jones A, Mansel RE, Jiang WG. The elevated level of CXCR4 is correlated with nodal metastasis of human breast cancer. Breast (2005) 14(5):360-7. doi:10.1016/j.breast.2004.12.007

124. Kang Y, Siegel PM, Shu W, Drobnjak M, Kakonen SM, Cordon-Cardo C, et al. A multigenic program mediating breast cancer metastasis to bone. Cancer Cell (2003) 3(6):537-49. doi:10.1016/S1535-6108(03)00132-6 
125. Katayama A, Ogino T, Bandoh N, Nonaka S, Harabuchi Y. Expression of CXCR4 and its down-regulation by IFN-gamma in head and neck squamous cell carcinoma. Clin Cancer Res (2005) 11(8):2937-46. doi:10.1158/1078-0432.CCR04- 1470

126. Kim J, Mori T, Chen SL, Amersi FF, Martinez SR, Kuo C, et al. Chemokine receptor CXCR4 expression in patients with melanoma and colorectal cancer liver metastases and the association with disease outcome. Ann Surg (2006) 244(1):113-20. doi:10.1097/01.sla.0000217690.65909.9c

127. Koishi K, Yoshikawa R, Tsujimura T, Hashimoto-Tamaoki T, Kojima S, Yanagi $\mathrm{H}$, et al. Persistent CXCR4 expression after preoperative chemoradiotherapy predicts early recurrence and poor prognosis in esophageal cancer. World $J$ Gastroenterol (2006) 12(47):7585-90. doi:10.3748/wjg.v12.i47.7585

128. Liang Z, Wu T, Lou H, Yu X, Taichman RS, Lau SK, et al. Inhibition of breast cancer metastasis by selective synthetic polypeptide against CXCR4. Cancer Res (2004) 64(12):4302-8. doi:10.1158/0008-5472.CAN-03-3958

129. Lopez-Giral S, Quintana NE, Cabrerizo M, Alfonso-Perez M, Sala-Valdes M, De Soria VG, et al. Chemokine receptors that mediate B cell homing to secondary lymphoid tissues are highly expressed in B cell chronic lymphocytic leukemia and non-Hodgkin lymphomas with widespread nodular dissemination. J Leukoc Biol (2004) 76(2):462-71. doi:10.1189/jlb.1203652

130. Marchesi F, Monti P, Leone BE, Zerbi A, Vecchi A, Piemonti L, et al. Increased survival, proliferation, and migration in metastatic human pancreatic tumor cells expressing functional CXCR4. Cancer Res (2004) 64(22):8420-7. doi:10. 1158/0008-5472.CAN-04-1343

131. Marechal R, Demetter P, Nagy N, Berton A, Decaestecker C, Polus M, et al. High expression of CXCR4 may predict poor survival in resected pancreatic adenocarcinoma. Br J Cancer (2009) 100(9):1444-51. doi:10.1038/sj.bjc.6605020

132. Matsusue R, Kubo H, Hisamori S, Okoshi K, Takagi H, Hida K, et al. Hepatic stellate cells promote liver metastasis of colon cancer cells by the action of SDF1/CXCR4 axis. Ann Surg Oncol (2009) 16(9):2645-53. doi:10.1245/s10434009-0599-x

133. Milliken D, Scotton C, Raju S, Balkwill F, Wilson J. Analysis of chemokines and chemokine receptor expression in ovarian cancer ascites. Clin Cancer Res (2002) 8(4):1108-14.

134. Minn AJ, Gupta GP, Siegel PM, Bos PD, Shu W, Giri DD, et al. Genes that mediate breast cancer metastasis to lung. Nature (2005) 436(7050):518-24. doi:10.1038/nature03799

135. Muller A, Sonkoly E, Eulert C, Gerber PA, Kubitza R, Schirlau K, et al. Chemokine receptors in head and neck cancer: association with metastatic spread and regulation during chemotherapy. Int J Cancer (2006) 118(9):2147-57. doi:10.1002/ijc.21514

136. Murakami T, Cardones AR, Hwang ST. Chemokine receptors and melanoma metastasis. J Dermatol Sci (2004) 36(2):71-8. doi:10.1016/j.jdermsci.2004.03. 002

137. O’Hayre M, Salanga CL, Kipps TJ, Messmer D, Dorrestein PC, Handel TM. Elucidating the CXCL12/CXCR4 signaling network in chronic lymphocytic leukemia through phosphoproteomics analysis. PLoS One (2010) 5(7):el1716. doi:10.1371/journal.pone.0011716

138. Oda Y, Ohishi Y, Basaki Y, Kobayashi H, Hirakawa T, Wake N, et al. Prognostic implications of the nuclear localization of Y-box-binding protein-1 and CXCR4 expression in ovarian cancer: their correlation with activated Akt, LRP/MVP and P-glycoprotein expression. Cancer Sci (2007) 98(7):1020-6. doi:10.1111/j.1349-7006.2007.00492.x

139. Oda Y, Yamamoto H, Tamiya S, Matsuda S, Tanaka K, Yokoyama R, et al. CXCR4 and VEGF expression in the primary site and the metastatic site of human osteosarcoma: analysis within a group of patients, all of whom developed lung metastasis. Modern Pathol (2006) 19(5):738-45. doi:10.1038/modpathol. 3800587

140. Phillips RJ, Burdick MD, Lutz M, Belperio JA, Keane MP, Strieter RM. The stromal derived factor-1/CXCL12-CXC chemokine receptor 4 biological axis in non-small cell lung cancer metastases. Am J Respir Crit Care Med (2003) 167(12):1676-86. doi:10.1164/rccm.200301-071OC

141. Raman D, Baugher PJ, Thu YM, Richmond A. Role of chemokines in tumor growth. Cancer Lett (2007) 256(2):137-65. doi:10.1016/j.canlet.2007.05.013

142. Russell HV, Hicks J, Okcu MF, Nuchtern JG. CXCR4 expression in neuroblastoma primary tumors is associated with clinical presentation of bone and bone marrow metastases. J Pediatr Surg (2004) 39(10):1506-11. doi:10.1016/j. jpedsurg.2004.06.019
143. Saur D, Seidler B, Schneider G, Algul H, Beck R, Senekowitsch-Schmidtke R, et al. CXCR4 expression increases liver and lung metastasis in a mouse model of pancreatic cancer. Gastroenterology (2005) 129(4):1237-50. doi:10.1053/j. gastro.2005.06.056

144. Scala S, Giuliano P, Ascierto PA, Ierano C, Franco R, Napolitano M, et al. Human melanoma metastases express functional CXCR4. Clin Cancer Res (2006) 12(8):2427-33. doi:10.1158/1078-0432.CCR-05-1940

145. Sun X, Cheng G, Hao M, Zheng J, Zhou X, Zhang J, et al. CXCL12/CXCR4/ CXCR7 chemokine axis and cancer progression. Cancer Metastasis Rev (2010) 29(4):709-22. doi:10.1007/s10555-010-9256-x

146. Vindrieux D, Escobar P, Lazennec G. Emerging roles of chemokines in prostate cancer. Endocr Relat Cancer (2009) 16(3):663-73. doi:10.1677/ERC-09-0109

147. Yasumoto K, Koizumi K, Kawashima A, Saitoh Y, Arita Y, Shinohara K, et al. Role of the CXCL12/CXCR4 axis in peritoneal carcinomatosis of gastric cancer. Cancer Res (2006) 66(4):2181-7. doi:10.1158/0008-5472.CAN-05-3393

148. Ying J, Xu Q, Zhang G, Liu B, Zhu L. The expression of CXCL12 and CXCR4 in gastric cancer and their correlation to lymph node metastasis. Med Oncol (2012) 29(3):1716-22. doi:10.1007/s12032-011-9990-0

149. Borsig L, Wolf MJ, Roblek M, Lorentzen A, Heikenwalder M. Inflammatory chemokines and metastasis - tracing the accessory. Oncogene (2014) 33(25):3217-24. doi:10.1038/onc.2013.272

150. Marchesi F, Piemonti L, Fedele G, Destro A, Roncalli M, Albarello L, et al. The chemokine receptor CX3CR1 is involved in the neural tropism and malignant behavior of pancreatic ductal adenocarcinoma. Cancer Res (2008) 68(21):9060-9. doi:10.1158/0008-5472.CAN-08-1810

151. Cho YB, Lee WY, Choi SJ, Kim J, Hong HK, Kim SH, et al. CC chemokine ligand 7 expression in liver metastasis of colorectal cancer. Oncol Rep (2012) 28(2):689-94. doi:10.3892/or.2012.1815

152. Hirai H, Fujishita T, Kurimoto K, Miyachi H, Kitano S, Inamoto S, et al. CCR1-mediated accumulation of myeloid cells in the liver microenvironment promoting mouse colon cancer metastasis. Clin Exp Metastasis (2014) 31(8):977-89. doi:10.1007/s10585-014-9684-z

153. Itatani Y, Kawada K, Fujishita T, Kakizaki F, Hirai H, Matsumoto T, et al. Loss of SMAD4 from colorectal cancer cells promotes CCL15 expression to recruit CCR1+ myeloid cells and facilitate liver metastasis. Gastroenterology (2013) 145(5):1064-75e11. doi:10.1053/j.gastro.2013.07.033

154. Kitamura T, Fujishita T, Loetscher P, Revesz L, Hashida H, Kizaka-Kondoh S, et al. Inactivation of chemokine (C-C motif) receptor 1 (CCR1) suppresses colon cancer liver metastasis by blocking accumulation of immature myeloid cells in a mouse model. Proc Natl Acad Sci U S A (2010) 107(29):13063-8. doi:10.1073/pnas.1002372107

155. Lu Y, Chen Q, Corey E, Xie W, Fan J, Mizokami A, et al. Activation of MCP$1 / \mathrm{CCR} 2$ axis promotes prostate cancer growth in bone. Clin Exp Metastasis (2009) 26(2):161-9. doi:10.1007/s10585-008-9226-7

156. Craig MJ, Loberg RD. CCL2 (Monocyte chemoattractant protein-1) in cancer bone metastases. Cancer Metastasis Rev (2006) 25(4):611-9. doi:10.1007/ s10555-006-9027-x

157. Loberg RD, Day LL, Harwood J, Ying C, St John LN, Giles R, et al. CCL2 is a potent regulator of prostate cancer cell migration and proliferation. Neoplasia (2006) 8(7):578-86. doi:10.1593/neo.06280

158. Vande Broek I, Asosingh K, Vanderkerken K, Straetmans N, Van Camp B, Van Riet I. Chemokine receptor CCR2 is expressed by human multiple myeloma cells and mediates migration to bone marrow stromal cell-produced monocyte chemotactic proteins MCP-1, -2 and -3. Br J Cancer (2003) 88(6):855-62. doi:10.1038/sj.bjc.6600833

159. Johrer K, Zelle-Rieser C, Perathoner A, Moser P, Hager M, Ramoner R, et al. Up-regulation of functional chemokine receptor CCR3 in human renal cell carcinoma. Clin Cancer Res (2005) 11(7):2459-65. doi:10.1158/1078-0432.CCR04-0405

160. Kleinhans M, Tun-Kyi A, Gilliet M, Kadin ME, Dummer R, Burg G, et al. Functional expression of the eotaxin receptor CCR3 in CD30+ cutaneous T-cell lymphoma. Blood (2003) 101(4):1487-93. doi:10.1182/blood-2002-020475

161. Ferenczi K, Fuhlbrigge RC, Pinkus J, Pinkus GS, Kupper TS. Increased CCR4 expression in cutaneous T cell lymphoma. J Invest Dermatol (2002) 119(6):1405-10. doi:10.1046/j.1523-1747.2002.19610.x

162. Ishida $\mathrm{T}$, Inagaki $\mathrm{H}$, Utsunomiya A, Takatsuka $\mathrm{Y}$, Komatsu H, Iida S, et al. $\mathrm{CXC}$ chemokine receptor 3 and CC chemokine receptor 4 expression in T-cell 
and NK-cell lymphomas with special reference to clinicopathological significance for peripheral T-cell lymphoma, unspecified. Clin Cancer Res (2004) 10(16):5494-500. doi:10.1158/1078-0432.CCR-04-0371

163. Ishida T, Utsunomiya A, Iida S, Inagaki H, Takatsuka Y, Kusumoto S, et al. Clinical significance of CCR4 expression in adult T-cell leukemia/lymphoma: its close association with skin involvement and unfavorable outcome. Clin Cancer Res (2003) 9(10 Pt 1):3625-34.

164. Sokolowska-Wojdylo M, Wenzel J, Gaffal E, Lenz J, Speuser P, Erdmann S, et al. Circulating clonal CLA(+) and CD4(+) T cells in Sezary syndrome express the skin-homing chemokine receptors CCR4 and CCR10 as well as the lymph node-homing chemokine receptor CCR7. Br J Dermatol (2005) 152(2):258-64. doi:10.1111/j.1365-2133.2004.06325.x

165. Cambien B, Richard-Fiardo P, Karimdjee BF, Martini V, Ferrua B, Pitard B, et al. CCL5 neutralization restricts cancer growth and potentiates the targeting of PDGFRbeta in colorectal carcinoma. PLoS One (2011) 6(12):e28842. doi:10.1371/journal.pone.0028842

166. Velasco-Velazquez M, Jiao X, De La Fuente M, Pestell TG, Ertel A, Lisanti MP, et al. CCR 5 antagonist blocks metastasis of basal breast cancer cells. Cancer Res (2012) 72(15):3839-50. doi:10.1158/0008-5472.CAN-11-3917

167. Ghadjar P, Coupland SE, Na IK, Noutsias M, Letsch A, Stroux A, et al. Chemokine receptor CCR6 expression level and liver metastases in colorectal cancer. J Clin Oncol (2006) 24(12):1910-6. doi:10.1200/JCO.2005.04.1822

168. Liu J, Ke F, Xu Z, Liu Z, Zhang L, Yan S, et al. CCR6 is a prognostic marker for overall survival in patients with colorectal cancer, and its overexpression enhances metastasis in vivo. PLoS One (2014) 9(6):e101137. doi:10.1371/journal.pone.0101137

169. Rubie C, Oliveira V, Kempf K, Wagner M, Tilton B, Rau B, et al. Involvement of chemokine receptor CCR6 in colorectal cancer metastasis. Tumour Biol (2006) 27(3):166-74. doi:10.1159/000092777

170. Alfonso-Perez M, Lopez-Giral S, Quintana NE, Loscertales J, Martin-Jimenez P, Munoz C. Anti-CCR7 monoclonal antibodies as a novel tool for the treatment of chronic lymphocyte leukemia. J Leukoc Biol (2006) 79(6):1157-65. doi:10.1189/jlb.1105623

171. Buonamici S, Trimarchi T, Ruocco MG, Reavie L, Cathelin S, Mar BG, et al. CCR7 signalling as an essential regulator of CNS infiltration in T-cell leukaemia. Nature (2009) 459(7249):1000-4. doi:10.1038/nature08020

172. Cunningham HD, Shannon LA, Calloway PA, Fassold BC, Dunwiddie I, Vielhauer $\mathrm{G}$, et al. Expression of the $\mathrm{C}-\mathrm{C}$ chemokine receptor 7 mediates metastasis of breast cancer to the lymph nodes in mice. Transl Oncol (2010) 3(6):354-61. doi:10.1593/tlo.10178

173. Ding Y, Shimada Y, Maeda M, Kawabe A, Kaganoi J, Komoto I, et al. Association of CC chemokine receptor 7 with lymph node metastasis of esophageal squamous cell carcinoma. Clin Cancer Res (2003) 9(9):3406-12.

174. Gunther K, Leier J, Henning G, Dimmler A, Weissbach R, Hohenberger $\mathrm{W}$, et al. Prediction of lymph node metastasis in colorectal carcinoma by expression of chemokine receptor CCR7. Int J Cancer (2005) 116(5):726-33. doi:10.1002/ijc. 21123

175. Legler DF, Uetz-von Allmen E, Hauser MA. CCR7: roles in cancer cell dissemination, migration and metastasis formation. Int J Biochem Cell Biol (2014) 54:78-82. doi:10.1016/j.biocel.2014.07.002

176. Mashino K, Sadanaga N, Yamaguchi H, Tanaka F, Ohta M, Shibuta K, et al. Expression of chemokine receptor CCR7 is associated with lymph node metastasis of gastric carcinoma. Cancer Res (2002) 62(10):2937-41.

177. Takanami I. Overexpression of CCR7 mRNA in nonsmall cell lung cancer: correlation with lymph node metastasis. Int J Cancer (2003) 105(2):186-9. doi:10.1002/ijc. 11063

178. Takeuchi H, Fujimoto A, Tanaka M, Yamano T, Hsueh E, Hoon DS. CCL21 chemokine regulates chemokine receptor CCR7 bearing malignant melanoma cells. Clin Cancer Res (2004) 10(7):2351-8. doi:10.1158/1078-0432.CCR-030195

179. Till KJ, Lin K, Zuzel M, Cawley JC. The chemokine receptor CCR7 and alpha4 integrin are important for migration of chronic lymphocytic leukemia cells into lymph nodes. Blood (2002) 99(8):2977-84. doi:10.1182/blood.V99.8.2977

180. Qiuping Z, Qun L, Chunsong H, Xiaolian Z, Baojun H, Mingzhen Y, et al. Selectively increased expression and functions of chemokine receptor CCR9 on CD4+ T cells from patients with T-cell lineage acute lymphocytic leukemia. Cancer Res (2003) 63(19):6469-77.
181. Singh S, Singh UP, Stiles JK, Grizzle WE, Lillard JW Jr. Expression and functional role of CCR9 in prostate cancer cell migration and invasion. Clin Cancer Res (2004) 10(24):8743-50. doi:10.1158/1078-0432.CCR-04-0266

182. Johnson-Holiday C, Singh R, Johnson E, Singh S, Stockard CR, Grizzle WE, et al. CCL25 mediates migration, invasion and matrix metalloproteinase expression by breast cancer cells in a CCR9-dependent fashion. Int J Oncol (2011) 38(5):1279-85. doi:10.3892/ijo.2011.953

183. Amersi FF, Terando AM, Goto Y, Scolyer RA, Thompson JF, Tran AN, et al. Activation of CCR9/CCL25 in cutaneous melanoma mediates preferential metastasis to the small intestine. Clin Cancer Res (2008) 14(3):638-45. doi:10.1158/1078-0432.CCR-07-2025

184. Letsch A, Keilholz U, Schadendorf D, Assfalg G, Asemissen AM, Thiel E, et al. Functional CCR9 expression is associated with small intestinal metastasis. $J$ Invest Dermatol (2004) 122(3):685-90. doi:10.1111/j.0022-202X.2004.22315.x

185. Mirandola L, Chiriva-Internati M, Montagna D, Locatelli F, Zecca M, Ranzani $\mathrm{M}$, et al. Notch1 regulates chemotaxis and proliferation by controlling the CCchemokine receptors 5 and 9 in T cell acute lymphoblastic leukaemia. J Pathol (2012) 226(5):713-22. doi:10.1002/path.3015

186. van den Oord J. The CCR9-CCL25 axis mediates melanoma metastasis to the small intestine. Nat Clin Pract Oncol (2008) 5(8):440-1. doi:10.1038/ ncponc1174

187. Ben-Baruch A. Organ selectivity in metastasis: regulation by chemokines and their receptors. Clin Exp Metastasis (2008) 25(4):345-56. doi:10.1007/s10585007-9097-3

188. Kai H, Kadono T, Kakinuma T, Tomita M, Ohmatsu H, Asano Y, et al. CCR10 and CCL27 are overexpressed in cutaneous squamous cell carcinoma. Pathol Res Pract (2011) 207(1):43-8. doi:10.1016/j.prp.2010.10.007

189. Morales J, Homey B, Vicari AP, Hudak S, Oldham E, Hedrick J, et al. CTACK, a skin-associated chemokine that preferentially attracts skin-homing memory T cells. Proc Natl Acad Sci U S A (1999) 96(25):14470-5. doi:10.1073/pnas.96. 25.14470

190. Notohamiprodjo M, Segerer S, Huss R, Hildebrandt B, Soler D, Djafarzadeh R, et al. CCR10 is expressed in cutaneous T-cell lymphoma. Int J Cancer (2005) 115(4):641-7. doi:10.1002/ijc.20922

191. Payne AS, Cornelius LA. The role of chemokines in melanoma tumor growth and metastasis. J Invest Dermatol (2002) 118(6):915-22. doi:10.1046/j.15231747.2002.01725.x

192. Erreni M, Solinas G, Brescia P, Osti D, Zunino F, Colombo P, et al. Human glioblastoma tumours and neural cancer stem cells express the chemokine CX3CL1 and its receptor CX3CR1. Eur J Cancer (2010) 46(18):3383-92. doi:10.1016/j.ejca.2010.07.022

193. Ferretti E, Pistoia V, Corcione A. Role of fractalkine/CX3CL1 and its receptor in the pathogenesis of inflammatory and malignant diseases with emphasis on $B$ cell malignancies. Mediators Inflamm (2014) 2014:480941. doi:10.1155/2014/ 480941

194. Hart KM, Bak SP, Alonso A, Berwin B. Phenotypic and functional delineation of murine CX(3)CR1 monocyte-derived cells in ovarian cancer. Neoplasia (2009) 11(6):564-73.

195. Jamieson-Gladney WL, Zhang Y, Fong AM, Meucci O, Fatatis A. The chemokine receptor CX(3)CR1 is directly involved in the arrest of breast cancer cells to the skeleton. Breast Cancer Res (2011) 13(5):R91. doi:10.1186/bcr3016

196. Kim M, Rooper L, Xie J, Kajdacsy-Balla AA, Barbolina MV. Fractalkine receptor CX(3)CR1 is expressed in epithelial ovarian carcinoma cells and required for motility and adhesion to peritoneal mesothelial cells. Mol Cancer Res (2012) 10(1):11-24. doi:10.1158/1541-7786.MCR-11-0256

197. Marchesi F, Locatelli M, Solinas G, Erreni M, Allavena P, Mantovani A. Role of CX3CR1/CX3CL1 axis in primary and secondary involvement of the nervous system by cancer. J Neuroimmunol (2010) 224(1-2):39-44. doi:10.1016/ j.jneuroim.2010.05.007

198. Nevo I, Sagi-Assif O, Meshel T, Ben-Baruch A, Johrer K, Greil R, et al. The involvement of the fractalkine receptor in the transmigration of neuroblastoma cells through bone-marrow endothelial cells. Cancer Lett (2009) 273(1):127-39. doi:10.1016/j.canlet.2008.07.029

199. Shulby SA, Dolloff NG, Stearns ME, Meucci O, Fatatis A. CX3CR1-fractalkine expression regulates cellular mechanisms involved in adhesion, migration, and survival of human prostate cancer cells. Cancer Res (2004) 64(14):4693-8. doi:10.1158/0008-5472.CAN-03-3437 
200. Zheng J, Yang M, Shao J, Miao Y, Han J, Du J. Chemokine receptor CX3CR1 contributes to macrophage survival in tumor metastasis. Mol Cancer (2013) 12(1):141. doi:10.1186/1476-4598-12-141

201. Grymula K, Tarnowski M, Wysoczynski M, Drukala J, Barr FG, Ratajczak J, et al. Overlapping and distinct role of CXCR7-SDF-1/ITAC and CXCR4-SDF1 axes in regulating metastatic behavior of human rhabdomyosarcomas. Int J Cancer (2010) 127(11):2554-68. doi:10.1002/ijc.25245

202. Iwakiri S, Mino N, Takahashi T, Sonobe M, Nagai S, Okubo K, et al. Higher expression of chemokine receptor CXCR7 is linked to early and metastatic recurrence in pathological stage I nonsmall cell lung cancer. Cancer (2009) 115(11):2580-93. doi:10.1002/cncr.24281

203. Miao Z, Luker KE, Summers BC, Berahovich R, Bhojani MS, Rehemtulla A, et al. CXCR7 (RDC1) promotes breast and lung tumor growth in vivo and is expressed on tumor-associated vasculature. Proc Natl Acad Sci U S A (2007) 104(40):15735-40. doi:10.1073/pnas.0610444104

204. Salmaggi A, Maderna E, Calatozzolo C, Gaviani P, Canazza A, Milanesi I, et al. CXCL12, CXCR4 and CXCR7 expression in brain metastases. Cancer Biol Ther (2009) 8(17):1608-14. doi:10.4161/cbt.8.17.9202

205. Zabel BA, Lewen S, Berahovich RD, Jaen JC, Schall TJ. The novel chemokine receptor CXCR7 regulates trans-endothelial migration of cancer cells. Mol Cancer (2011) 10:73. doi:10.1186/1476-4598-10-73

206. Chen J, Yao Y, Gong C, Yu F, Su S, Chen J, et al. CCL18 from tumor-associated macrophages promotes breast cancer metastasis via PITPNM3. Cancer Cell (2011) 19(4):541-55. doi:10.1016/j.ccr.2011.02.006

207. Chames P, Van Regenmortel M, Weiss E, Baty D. Therapeutic antibodies: successes, limitations and hopes for the future. Br J Pharmacol (2009) 157(2):220-33. doi:10.1111/j.1476-5381.2009.00190.x

208. Glassman PM, Balthasar JP. Mechanistic considerations for the use of monoclonal antibodies for cancer therapy. Cancer Biol Med (2014) 11(1):20-33. doi:10.7497/j.issn.2095-3941.2014.01.002

209. Scott AM, Wolchok JD, Old LJ. Antibody therapy of cancer. Nat Rev Cancer (2012) 12(4):278-87. doi:10.1038/nrc3236

210. Zhang Q, Chen G, Liu X, Qian Q. Monoclonal antibodies as therapeutic agents in oncology and antibody gene therapy. Cell Res (2007) 17(2):89-99. doi:10.1038/sj.cr.7310143

211. Imai K, Takaoka A. Comparing antibody and small-molecule therapies for cancer. Nat Rev Cancer (2006) 6(9):714-27. doi:10.1038/nrc1913

212. Reichert JM, Rosensweig CJ, Faden LB, Dewitz MC. Monoclonal antibody successes in the clinic. Nat Biotechnol (2005) 23(9):1073-8. doi:10.1038/nbt09051073

213. Kola I, Landis J. Can the pharmaceutical industry reduce attrition rates? Nat Rev Drug Discov (2004) 3(8):711-5. doi:10.1038/nrd1470

214. Reichert JM, Dhimolea E. The future of antibodies as cancer drugs. Drug Discov Today (2012) 17(17-18):954-63. doi:10.1016/j.drudis.2012.04.006

215. Yushak M, Kluger HM, Sznol M. Advances in the systemic treatment of metastatic melanoma. Oncology (2013) 27(5). pii:168980

216. Blank CU. The perspective of immunotherapy: new molecules and new mechanisms of action in immune modulation. Curr Opin Oncol (2014) 26(2):204-14. doi:10.1097/CCO.0000000000000054

217. Kyi C, Postow MA. Checkpoint blocking antibodies in cancer immunotherapy. FEBS Lett (2014) 588(2):368-76. doi:10.1016/j.febslet.2013.10.015

218. Vonderheide RH, Glennie MJ. Agonistic CD40 antibodies and cancer therapy. Clin Cancer Res (2013) 19(5):1035-43. doi:10.1158/1078-0432.CCR-12-2064

219. Melero I, Hervas-Stubbs S, Glennie M, Pardoll DM, Chen L. Immunostimulatory monoclonal antibodies for cancer therapy. Nat Rev Cancer (2007) 7(2):95-106. doi:10.1038/nrc2051

220. Klarenbeek AMD, Blanchetot C, Saunders M, van der Woning S, Smit M, de Haard H, et al. Targeting chemokines and chemokine receptors with antibodies. Drug Discov Today Technol (2012) 9(4):e227-314. doi:10.1016/j.ddtec.2012. 09.006

221. Kremer L, Marquez G. Generation of monoclonal antibodies against chemokine receptors. Methods Mol Biol (2004) 239:243-60.

222. Ponath PD, Kassam N, Qin S. Monoclonal antibodies to chemokine receptors. Methods Mol Biol (2000) 138:231-42. doi:10.1385/1-59259-058-6:231

223. Schall TJ, Proudfoot AE. Overcoming hurdles in developing successful drugs targeting chemokine receptors. Nat Rev Immunol (2011) 11(5):355-63. doi:10. $1038 /$ nri2972
224. Vergunst CE, Gerlag DM, Lopatinskaya L, Klareskog L, Smith MD, van den Bosch F, et al. Modulation of CCR2 in rheumatoid arthritis: a doubleblind, randomized, placebo-controlled clinical trial. Arthritis Rheum (2008) 58(7):1931-9. doi:10.1002/art.23591

225. Ben S, Li X, Xu F, Xu W, Li W, Wu Z, et al. Treatment with anti-CC chemokine receptor 3 monoclonal antibody or dexamethasone inhibits the migration and differentiation of bone marrow CD34 progenitor cells in an allergic mouse model. Allergy (2008) 63(9):1164-76. doi:10.1111/j.1398-9995.2008. 01747.x

226. Catley MC, Coote J, Bari M, Tomlinson KL. Monoclonal antibodies for the treatment of asthma. Pharmacol Ther (2011) 132(3):333-51. doi:10.1016/j. pharmthera.2011.09.005

227. Perros F, Hoogsteden HC, Coyle AJ, Lambrecht BN, Hammad H. Blockade of CCR4 in a humanized model of asthma reveals a critical role for DC-derived CCL17 and CCL22 in attracting Th2 cells and inducing airway inflammation. Allergy (2009) 64(7):995-1002. doi:10.1111/j.1398-9995.2009.02095.x

228. Wang K, Shen HH, Li W, Huang HQ. Human C-C chemokine receptor 3 monoclonal antibody inhibits pulmonary inflammation in allergic mice. Acta Pharmacol Sin (2007) 28(11):1791-6. doi:10.1111/j.1745-7254.2007.00635.x

229. Carnec X, Quan L, Olson WC, Hazan U, Dragic T. Anti-CXCR4 monoclonal antibodies recognizing overlapping epitopes differ significantly in their ability to inhibit entry of human immunodeficiency virus type 1. J Virol (2005) 79(3):1930-3. doi:10.1128/JVI.79.3.1930-1933.2005

230. Olson WC, Jacobson JM. CCR5 monoclonal antibodies for HIV-1 therapy. Curr Opin HIV AIDS (2009) 4(2):104-11. doi:10.1097/COH.0b013e3283224015

231. Pierce EM, Carpenter K, Jakubzick C, Kunkel SL, Flaherty KR, Martinez FJ, et al. Therapeutic targeting of CC ligand 21 or CC chemokine receptor 7 abrogates pulmonary fibrosis induced by the adoptive transfer of human pulmonary fibroblasts to immunodeficient mice. Am J Pathol (2007) 170(4):1152-64. doi:10.2353/ajpath.2007.060649

232. Kuhne MR, Mulvey T, Belanger B, Chen S, Pan C, Chong C, et al. BMS936564/MDX-1338: a fully human anti-CXCR4 antibody induces apoptosis in vitro and shows antitumor activity in vivo in hematologic malignancies. Clin Cancer Res (2013) 19(2):357-66. doi:10.1158/1078-0432.CCR-12-2333

233. Ishii T, Ishida T, Utsunomiya A, Inagaki A, Yano H, Komatsu H, et al. Defucosylated humanized anti-CCR4 monoclonal antibody KW-0761 as a novel immunotherapeutic agent for adult T-cell leukemia/lymphoma. Clin Cancer Res (2010) 16(5):1520-31. doi:10.1158/1078-0432.CCR-09-2697

234. Hattermann K, Held-Feindt J, Lucius R, Muerkoster SS, Penfold ME, Schall TJ, et al. The chemokine receptor CXCR7 is highly expressed in human glioma cells and mediates antiapoptotic effects. Cancer Res (2010) 70(8):3299-308. doi:10.1158/0008-5472.CAN-09-3642

235. Balkwill FR. The chemokine system and cancer. J Pathol (2012) 226(2):148-57. doi:10.1002/path.3029

236. Allavena P, Germano G, Marchesi F, Mantovani A. Chemokines in cancer related inflammation. Exp Cell Res (2011) 317(5):664-73. doi:10.1016/j.yexcr. 2010.11.013

237. Chatterjee S, Behnam Azad B, Nimmagadda S. The intricate role of CXCR4 in cancer. Adv Cancer Res (2014) 124:31-82. doi:10.1016/B978-0-12-411638-2. 00002-1

238. Lu X, Kang Y. Chemokine (C-C motif) ligand 2 engages CCR2+ stromal cells of monocytic origin to promote breast cancer metastasis to lung and bone. $J$ Biol Chem (2009) 284(42):29087-96. doi:10.1074/jbc.M109.035899

239. Acosta-Rodriguez EV, Rivino L, Geginat J, Jarrossay D, Gattorno M, Lanzavecchia $A$, et al. Surface phenotype and antigenic specificity of human interleukin 17-producing T helper memory cells. Nat Immunol (2007) 8(6):639-46. doi:10.1038/ni1467

240. Bonecchi R, Bianchi G, Bordignon PP, D’Ambrosio D, Lang R, Borsatti A, et al. Differential expression of chemokine receptors and chemotactic responsiveness of type 1 T helper cells (Th1s) and Th2s. J Exp Med (1998) 187(1):129-34. doi:10.1084/jem.187.1.129

241. Campbell JJ, Haraldsen G, Pan J, Rottman J, Qin S, Ponath P, et al. The chemokine receptor CCR4 in vascular recognition by cutaneous but not intestinal memory T cells. Nature (1999) 400(6746):776-80. doi:10.1038/23495

242. Ishida T, Ishii T, Inagaki A, Yano H, Kusumoto S, Ri M, et al. The CCR4 as a novel-specific molecular target for immunotherapy in Hodgkin lymphoma. Leukemia (2006) 20(12):2162-8. doi:10.1038/sj.leu.2404415 
243. Lonsdorf AS, Hwang ST, Enk AH. Chemokine receptors in T-cell-mediated diseases of the skin. J Invest Dermatol (2009) 129(11):2552-66. doi:10.1038/ jid.2009.122

244. Niwa R, Shoji-Hosaka E, Sakurada M, Shinkawa T, Uchida K, Nakamura $\mathrm{K}$, et al. Defucosylated chimeric anti-CC chemokine receptor 4 IgG1 with enhanced antibody-dependent cellular cytotoxicity shows potent therapeutic activity to T-cell leukemia and lymphoma. Cancer Res (2004) 64(6):2127-33. doi:10.1158/0008-5472.CAN-03-2068

245. Shinkawa T, Nakamura K, Yamane N, Shoji-Hosaka E, Kanda Y, Sakurada M, et al. The absence of fucose but not the presence of galactose or bisecting $\mathrm{N}$ acetylglucosamine of human IgG1 complex-type oligosaccharides shows the critical role of enhancing antibody-dependent cellular cytotoxicity. J Biol Chem (2003) 278(5):3466-73. doi:10.1074/jbc.M210665200

246. Ito A, Ishida T, Utsunomiya A, Sato F, Mori F, Yano H, et al. Defucosylated anti-CCR4 monoclonal antibody exerts potent ADCC against primary ATLL cells mediated by autologous human immune cells in NOD/Shiscid, IL-2R gamma(null) mice in vivo. J Immunol (2009) 183(7):4782-91. doi:10.4049/jimmunol.0900699

247. Ito Y, Miyamoto T, Chong Y, Aoki T, Kato K, Akashi K, et al. Successful treatment with anti-CC chemokine receptor $4 \mathrm{MoAb}$ of relapsed adult T-cell leukemia/lymphoma after umbilical cord blood transplantation. Bone Marrow Transplant (2013) 48(7):998-9. doi:10.1038/bmt.2012.268

248. Yamamoto K, Utsunomiya A, Tobinai K, Tsukasaki K, Uike N, Uozumi K, et al. Phase I study of KW-0761, a defucosylated humanized anti-CCR4 antibody, in relapsed patients with adult T-cell leukemia-lymphoma and peripheral T-cell lymphoma. J Clin Oncol (2010) 28(9):1591-8. doi:10.1200/JCO.2009.25.3575

249. Kanazawa T, Hiramatsu Y, Iwata S, Siddiquey M, Sato Y, Suzuki M, et al. Anti-CCR4 monoclonal antibody mogamulizumab for the treatment of EBVassociated T- and NK-cell lymphoproliferative diseases. Clin Cancer Res (2014) 20(19):5075-84. doi:10.1158/1078-0432.CCR-14-0580

250. Facciabene A, Motz GT, Coukos G. T-regulatory cells: key players in tumor immune escape and angiogenesis. Cancer Res (2012) 72(9):2162-71. doi:10. 1158/0008-5472.CAN-11-3687

251. Ni X, Jorgensen JL, Goswami M, Challagundla P, Decker WK, Kim YH, et al. Reduction of regulatory $\mathrm{T}$ cells by mogamulizumab, a defucosylated anti-CC chemokine receptor 4 antibody, in patients with aggressive/refractory mycosis fungoides and Sézary syndrome. Clin Cancer Res (2014). doi:10.1158/10780432.CCR-14-0830

252. Kurose K, Ohue Y, Sato E, Yamauchi A, Eikawa S, Isobe M, et al. Increase in activated Treg in TIL in lung cancer and in vitro depletion of Treg by ADCC using an anti-human CCR4 mAb (KM2760). J Thorac Oncol (2014). doi:10.1097/JTO.0000000000000364

253. Ishida $\mathrm{T}$, Ito $\mathrm{A}$, Sato $\mathrm{F}$, Kusumoto $\mathrm{S}$, Iida $\mathrm{S}$, Inagaki $\mathrm{H}$, et al. StevensJohnson syndrome associated with mogamulizumab treatment of adult T-cell leukemia/lymphoma. Cancer Sci (2013) 104(5):647-50. doi:10.1111/cas.12116

254. Yonekura K, Kanzaki T, Gunshin K, Kawakami N, Takatsuka Y, Nakano N, et al. Effect of anti-CCR4 monoclonal antibody (mogamulizumab) on adult T-cell leukemia-lymphoma: cutaneous adverse reactions may predict the prognosis. J Dermatol (2014) 41(3):239-44. doi:10.1111/1346-8138.12419

255. Nakano N, Kusumoto S, Tanaka Y, Ishida T, Takeuchi S, Takatsuka Y, et al. Reactivation of hepatitis B virus in a patient with adult T-cell leukemia-lymphoma receiving the anti-CC chemokine receptor 4 antibody mogamulizumab. Hepatol Res (2014) 44(3):354-7. doi:10.1111/hepr.12117

256. Kato K, Miyamoto T, Numata A, Nakaike T, Oka H, Yurino A, et al. Diffuse panbronchiolitis after humanized anti-CCR4 monoclonal antibody therapy for relapsed adult T-cell leukemia/lymphoma. Int J Hematol (2013) 97(3):430-2. doi:10.1007/s12185-013-1278-z

257. Han T, Abdel-Motal UM, Chang DK, Sui J, Muvaffak A, Campbell J, et al. Human anti-CCR4 minibody gene transfer for the treatment of cutaneous T-cell lymphoma. PLoS One (2012) 7(9):e44455. doi:10.1371/journal.pone. 0044455

258. Saintigny P, Massarelli E, Lin S, Ahn YH, Chen Y, Goswami S, et al. CXCR2 expression in tumor cells is a poor prognostic factor and promotes invasion and metastasis in lung adenocarcinoma. Cancer Res (2013) 73(2):571-82. doi:10.1158/0008-5472.CAN-12-0263

259. Jamieson T, Clarke M, Steele CW, Samuel MS, Neumann J, Jung A, et al. Inhibition of CXCR2 profoundly suppresses inflammation-driven and spontaneous tumorigenesis. J Clin Invest (2012) 122(9):3127-44. doi:10.1172/JCI61067
260. Matsuo Y, Raimondo M, Woodward TA, Wallace MB, Gill KR, Tong Z, et al. CXC-chemokine/CXCR2 biological axis promotes angiogenesis in vitro and in vivo in pancreatic cancer. Int J Cancer (2009) 125(5):1027-37. doi:10.1002/ ijc. 24383

261. Matsuo Y, Ochi N, Sawai H, Yasuda A, Takahashi H, Funahashi H, et al. CXCL8/IL-8 and CXCL12/SDF-1alpha co-operatively promote invasiveness and angiogenesis in pancreatic cancer. Int J Cancer (2009) 124(4):853-61. doi:10.1002/ijc. 24040

262. Heidemann J, Ogawa H, Dwinell MB, Rafiee P, Maaser C, Gockel HR, et al. Angiogenic effects of interleukin 8 (CXCL8) in human intestinal microvascular endothelial cells are mediated by CXCR2. J Biol Chem (2003) 278(10):8508-15. doi:10.1074/jbc.M208231200

263. Strieter RM, Burdick MD, Mestas J, Gomperts B, Keane MP, Belperio JA. Cancer CXC chemokine networks and tumour angiogenesis. Eur J Cancer (2006) 42(6):768-78. doi:10.1016/j.ejca.2006.01.006

264. Corvaia NBS, Wurch T, Boute N, Broussas M, Beau-Larvor C, Akla B, et al. 515H7, a novel anti-CXCR4 antibody: in vitro efficacy on CXCR4-associated signaling pathways and in vivo anti-tumor activity. Proceedings of the 102nd Annual Meeting of the American Association for Cancer Research; 2011 Apr 2-6. (Vol. 71), Orlando, FL Philadelphia, PA: AACR (2011).

265. Boynton AL. CXCR4 is involved in multiple functions of cancer cells and is a compelling target for monoclonal antibody-based therapeutics. Abstract retrieved from Abstracts in ASCO Annual Meeting Proceedings (Post-Meeting Edition). J Clin Oncol (2006) 24(18 Suppl):Abstr20013.

266. Keating GM. Plerixafor: a review of its use in stem-cell mobilization in patients with lymphoma or multiple myeloma. Drugs (2011) 71(12):1623-47. doi:10.2165/11206040-000000000-00000

267. Ramsey DM, McAlpine SR. Halting metastasis through CXCR4 inhibition. Bioorg Med Chem Lett (2013) 23(1):20-5. doi:10.1016/j.bmcl.2012.10.138

268. Azab AK, Runnels JM, Pitsillides C, Moreau AS, Azab F, Leleu X, et al. CXCR4 inhibitor AMD3100 disrupts the interaction of multiple myeloma cells with the bone marrow microenvironment and enhances their sensitivity to therapy. Blood (2009) 113(18):4341-51. doi:10.1182/blood-2008-10-186668

269. Domanska UM, Kruizinga RC, Nagengast WB, Timmer-Bosscha H, Huls G, de Vries EG, et al. A review on CXCR4/CXCL12 axis in oncology: no place to hide. Eur J Cancer (2013) 49(1):219-30. doi:10.1016/j.ejca.2012.05.005

270. Domanska UM, Timmer-Bosscha H, Nagengast WB, Oude Munnink TH, Kruizinga RC, Ananias HJ, et al. CXCR4 inhibition with AMD3100 sensitizes prostate cancer to docetaxel chemotherapy. Neoplasia (2012) 14(8):709-18.

271. Redjal N, Chan JA, Segal RA, Kung AL. CXCR4 inhibition synergizes with cytotoxic chemotherapy in gliomas. Clin Cancer Res (2006) 12(22):6765-71. doi:10.1158/1078-0432.CCR-06-1372

272. Ma Y, Adjemian S, Galluzzi L, Zitvogel L, Kroemer G. Chemokines and chemokine receptors required for optimal responses to anticancer chemotherapy. Oncoimmunology (2014) 3(1):e27663. doi:10.4161/onci.27663

273. Ma Y, Mattarollo SR, Adjemian S, Yang H, Aymeric L, Hannani D, et al. CCL2/CCR2-dependent recruitment of functional antigen-presenting cells into tumors upon chemotherapy. Cancer Res (2014) 74(2):436-45. doi:10. 1158/0008-5472.CAN-13-1265

Conflict of Interest Statement: The authors declare that the research was conducted in the absence of any commercial or financial relationships that could be construed as a potential conflict of interest.

Received: 03 December 2014; paper pending published: 23 December 2014; accepted: 07 January 2015; published online: 30 January 2015.

Citation: Vela M, Aris M, Llorente M, Garcia-Sanz JA and Kremer L (2015) Chemokine receptor-specific antibodies in cancer immunotherapy: achievements and challenges. Front. Immunol. 6:12. doi: 10.3389/fimmu.2015.00012

This article was submitted to Immunotherapies and Vaccines, a section of the journal Frontiers in Immunology.

Copyright (C) 2015 Vela, Aris, Llorente, Garcia-Sanz and Kremer. This is an openaccess article distributed under the terms of the Creative Commons Attribution License (CC BY). The use, distribution or reproduction in other forums is permitted, provided the original author(s) or licensor are credited and that the original publication in this journal is cited, in accordance with accepted academic practice. No use, distribution or reproduction is permitted which does not comply with these terms. 